\title{
Data report: Expedition 313 elemental data from X-ray fluorescence scanning and measurements on core samples ${ }^{1}$
}

\author{
J. Inwood, ${ }^{2}$ A. McGrath, ${ }^{2}$ S. Morgan, ${ }^{2}$ M. Norry, ${ }^{2}$ S. Davies, ${ }^{2}$ and H. Foster ${ }^{2}$
}

\section{Chapter contents}

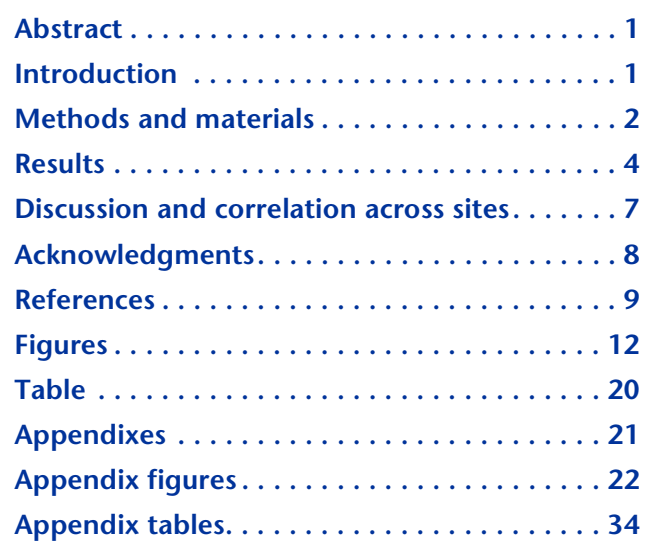

${ }^{1}$ Inwood, J., McGrath, A., Morgan, S., Norry, M., Davies, S., Foster, H., 2019. Data report: Expedition 313 elemental data from $\mathrm{X}$-ray fluorescence scanning and measurements on core samples. In Mountain, G., Proust, J.-N., Mclnroy, D., Cotterill, C., and the Expedition 313 Scientists, Proceedings of the Integrated Ocean Drilling Program, 313: Tokyo (Integrated Ocean Drilling Program Management International, Inc.). doi:10.2204/iodp.proc.313.203.2019 ${ }^{2}$ School of Geography, Geology and the Environment, University of Leicester, University Road, Leicester LE1 7RH, United Kingdom. Correspondence author: jenny.inwood@leicester.ac.uk

\section{Abstract}

Integrated Ocean Drilling Program Expedition 313 recovered siliciclastic sediments from three holes cored through a series of Miocene clinoforms offshore New Jersey. The clinoform sequence that lies between seismic reflectors $\mathrm{m} 5.2$ and $\mathrm{m} 4.1$ has been dated as mid-Miocene within an interval of major climatic change and displays interesting sedimentological and petrophysical features. However, the depth ties between surfaces in the recovered succession and seismic reflectors, correlation across sites, and depositional environments are not all well defined in this interval. Additionally, features observed in the two more proximal boreholes are absent from the most distal borehole.

This report presents X-ray fluorescence (XRF) measurements from scanning the split surface of archive sediment cores and from individual core samples from Holes M0027A, M0028A, and M0029A. Major trends are identified and described, aided by statistical analyses (correlation coefficient matrix plots and principal component analyses). Si/Al and $\mathrm{Zr} / \mathrm{Rb}$ ratios and, to a lesser extent, Th correspond with changes in the ratio of clay minerals to quartz. In the most proximal Hole M0027A, an alternating sequence of dark and light bands in an extended sequence of clays is characterized by distinctive high and variable magnetic susceptibility and equivalently variable $\mathrm{Fe} / \mathrm{S}$ ratios. A similar sequence is observed in Hole M0028A, with both sequences located above the inferred m4.1 seismic sequence boundary. Redox elements in this interval are highly variable and suggest the influence of postdepositional processes. In Hole M0029A, despite an expanded sequence, similar characteristics are absent from the clay sequences, which are also geochemically more homogeneous. The analyzed geochemical compositions are compared with sedimentological observations and petrophysical analyses before discussing in their wider context.

\section{Introduction}

$\mathrm{X}$-ray fluorescence (XRF) is a powerful tool for the analysis of marine sediments and has been commonly utilized during the Integrated Ocean Drilling Program (IODP). For example, XRF can be used to distinguish lithologic and mineralogic variation, to correlate across sites, to provide high-resolution geochemical records, and to add insight into syn- and postdepositional processes 
(e.g., Jansen et al., 1998; Kuhlmann et al., 2004; Lyle et al., 2012; Türke et al., 2014; Rothwell et al., 2006; Penkrot et al., 2017).

During IODP Expedition 313, siliciclastic sediments were recovered from Holes M0027A, M0028A, and M0029A. Each hole was drilled, cored, and logged through a series of Miocene clinoforms offshore New Jersey (Fig. F1A). These clinoforms are marked by recognized seismic reflectors, many of which were dated and correlated using microfossils in sediments recovered during Expedition 313. The siliciclastic sequences were divided into eight lithologic units that share similar sedimentological characteristics across holes (see the "Expedition 313 summary" chapter [Expedition 313 Scientists, 2010a]; Miller et al., 2013). The uppermost Miocene clinoform sequence analyzed in this report (Fig. F1B) lies between seismic reflectors $\mathrm{m} 5.2$ and $\mathrm{m} 4.1$ and in lithostratigraphic Unit II (Expedition 313 Scientists, 2010a) and has been dated as the mid-Miocene (Browning et al., 2013). This interval, therefore, lies in a period of significant climate change during global cooling following the middle Miocene climate optimum (Zachos et al., 2008).

Petrophysical data from this interval display interesting characteristics, including electrical conductivity changes that correspond to changes in pore water salinity (see the "Expedition 313 summary" chapter [Expedition 313 Scientists, 2010a]; Lofi et al., 2013), regions of high and variable magnetic susceptibility (Expedition 313 Scientists, 2010a) that correlate with rock magnetic changes (Nilsson et al., 2013), acoustic image surfaces that are not matched by sedimentological changes (Expedition 313 Scientists, 2010a), and intervals of high sonic velocity that correspond to cemented intervals (Expedition 313 Scientists, 2010a; Miller et al., 2013). In the holes that are more proximal to land (Holes M0027A and M0028A), this interval includes extended clay sequences where core recovery was $>100 \%$, suggestive of clay expansion, which has distinctive petrophysical characteristics (Expedition 313 Scientists, 2010a; Inwood et al., 2013; Inwood, 2018). However, correlation between the two more landward holes is not without ambiguity, nor is the stratal significance and precise locations within the core of seismic reflector $\mathrm{m} 4.1$ fully determined (Expedition 313 Scientists, 2010a; Miller et al., 2013). In Hole M0027A, diatoms die out at the base of the clay sequence (Barron et al., 2013), and terrestrial/marine ratios and foraminiferal observations indicate considerable water-depth variations (Katz et al., 2013; McCarthy et al., 2013; Kotthof et al., 2014). Furthermore, despite the interval further offshore in Hole M0029A representing an expanded succession, the distinctive petrophysical characteris- tics observed at the more proximal sites are not apparent, suggesting that these sediments were either eroded or not originally deposited. Therefore, the acquisition of geochemical data (XRF measurements on the split-core surface and on core samples) represents an opportunity to elucidate the depositional and postdepositional geochemical changes and produce a more complete story of the evolution of this interval.

The major objective of this report is to describe and evaluate the new XRF data obtained primarily from the interval between seismic reflectors $\mathrm{m} 4.5$ and $\mathrm{m} 4.1$, including $30 \mathrm{~m}$ of very high resolution measurements in Hole M0027A in the interval characterized by distinctive petrophysical changes. Major geochemical variations and trends are briefly discussed in relation to changes in lithology, seismic surfaces, pore water, and inferred depositional environments.

\section{Methods and materials}

XRF measurements on split-core surfaces (referred to hereafter as "XRF-core") and on individual core samples (referred to hereafter as "XRF-sample") were acquired for all three Expedition 313 holes (Table T1; Fig. F1B), focusing on the interval between seismic reflectors $\mathrm{m} 4.5$ and $\mathrm{m} 4.1$. In Hole M0027A, both XRF-core and XRF-sample measurements were acquired for all of lithostratigraphic Unit II and extend from seismic reflector $\mathrm{m} 5.2$ at the base uphole to reflector m4.1 (Table T1). In Hole M0028A, the upper part of Unit II was measured, with XRF-core measurements acquired in the clays between seismic reflectors $\mathrm{m} 4.5$ and $\mathrm{m} 4.1$ supported by interspersed XRF-sample measurements to correlate key trends across sites (Table T1). In Hole M0029A, in the thicker sequences of Unit II a program of targeted sampling was followed for XRF-sample measurements between seismic reflectors $\mathrm{m} 4.5$ and $\mathrm{m} 4.1$, with a small interval of XRF-core measurements in the uppermost clay near seismic reflector m4.1 (Table T1).

\section{Core depth shifts}

All core and section depths were obtained from the Expedition 313 legacy information found in the site chapters of this volume (see the "Site M0027," "Site M0028," and "Site M0029" chapters [Expedition 313 Scientists, 2010c, 2010d, 2010e]). At each site, notably in the clay sequences, core recovery was often recorded as $>100 \%$ (Inwood, 2018). In this report, the method of choice to avoid confusion and loss of resolution in overlapping intervals was to use the depth map provided in Tables AT1, AT2, and AT3 in "Appendix A" to scale core from its original 
depth (core depth below seafloor, Method A [CSF-A]) to core depth below seafloor, Method B (CSF-B) (see IODP Depth Scales Terminology at http://www.iodp.org/top-resources/program-documents/policies-and-guidelines). Overlap affects 10 of 26 cores recovered from Hole M0027A, 9 of 11 cores from Hole M0028A, and 18 of 53 cores from Hole M0029A (maximum extra recovery of $27 \%$, $14 \%$, and $15 \%$, respectively), and without scaling, considerable interpretation error could arise. Scaled depths (CSF-B) are used for all measurements taken on the core unless otherwise stated. Downhole logging depths are left unchanged from those reported (wireline depth below seafloor (WSF)/wireline matched depth below seafloor (WMSF) during Expedition 313 (see the Methods chapter [Expedition 313 Scientists, 2010b]).

Note that in Hole M0027A, Core $59 \mathrm{H}$ was left unscaled because it is in an interval of very low core recovery, with core positioning correspondingly uncertain and no overlap with adjacent cores. Overlaps with the underlying Cores 16R in Hole M0028A (following a reaming operation) and $104 \mathrm{R}$ in Hole M0029A (described as a slipped core) are considered to have resulted from drilling disturbance, and both cores were thus moved upward by the amount of overlap.

\section{Geochemical measurements on split core surfaces (XRF-core measurements)}

XRF core scanning provides a nondestructive analysis system for relatively fast, high-resolution analysis of major and minor elements (from $\mathrm{Mg}$ through $\mathrm{U}$ ) by scanning the surface of split sediment cores. The core surface was observed carefully to avoid collecting data from around cracks. XRF data were collected directly from the split core surface of the archive half every $1 \mathrm{~cm}$ downcore over a $1.2 \mathrm{~cm}^{2}$ area with an XRF Core Scanner II (AVAATECH; serial Number 2) at MARUM-University of Bremen using the following settings:

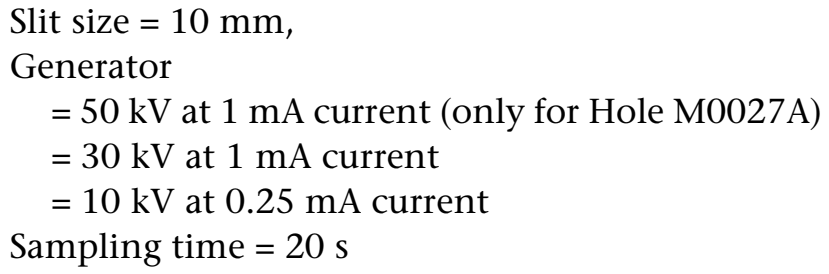

The split-core surface was covered with a $4 \mu \mathrm{m}$ thin SPEXCerti Prep Ultralene1 foil to avoid contamination of the XRF measurement unit and desiccation of the sediment. The data were acquired by a Canberra X-PIPS silicon drift detector (SDD; Model SXD 15C150-500) with $150 \mathrm{eV}$ X-ray resolution, a Canberra digital spectrum analyzer (DAS 1000), and an Oxford
Instruments 50W XTF5011 X-ray tube with rhodium (Rh) target material. Raw data were processed by analysis of X-ray spectra with iterative least-squares software (WIN AXIL) from Canberra Eurisys.

XRF count rates for the continuous core surfaces are influenced by factors that include sample matrix, sediment thickness, porosity (water content), and surface characteristics (e.g., Tjallingi et al., 2007). Direct count rates of individual elements must therefore be interpreted with caution, especially when comparing light and heavy elements or where measurements are closer to the noise level.

In "Appendix B," geochemical XRF core measurements are presented as downhole plots for Holes M0027A (Fig. BF1), M0028A (Fig. BF2), and M0029A (Fig. BF3) and as raw and normalized values (counts per second) (Table BT1). Elements that were measured but are unreliable or below the detection threshold were excluded.

\section{Geochemical measurements on individual samples (XRF-sample measurements)}

Conventional XRF measurements were obtained from individual samples from Holes M0027A (118 samples), M0028A (21 samples), and M0029A (60 samples). All whole rock samples were prepared using standard methods (Pickering et al., 1993; Tarney and Marsh, 1991). Major and trace element data were obtained from fusion beads and pressed powder pellets, respectively, by XRF analysis using a PANalytical Axios Advanced X-Ray fluorescence spectrometer at the University of Leicester, United Kingdom. Total loss on ignition (LOI) was measured on predried powders. The PANalytical Axios runs a $4 \mathrm{~kW} \mathrm{Rh}$ anode end-window supersharp ceramic technology X-ray tube. Samples are loaded from a 96-position sample changer when configured for $32 \mathrm{~mm}$ diameter fusion beads or pellets. The control and processing software was the PANalytical SuperQ system with IQ+, WROXI, and ProTrace extensions. Calibrations were set using international rock reference materials under the same conditions and regressing the measured count ratios against recommended concentrations (after Govindaraju et al., 1994; Imai et al., 1995; see also http://georem.mpch-mainz.gwdg.de).

Geochemical XRF-sample measurements are presented as downhole plots for Holes M0027A, M0028A, and M0029A (Figs. CF1, CF2, CF3 in "Appendix $C^{\prime \prime}$ ) and as major element oxides in weight percent and trace elements in parts per million in Tables CT1, CT2, and CT3 in "Appendix C." Where values approach the noise level or were inappropriate for analysis for other reasons, $\mathrm{Br}, \mathrm{Cl}, \mathrm{Cs}, \mathrm{Sb}, \mathrm{Se}$, 
$\mathrm{Sn}, \mathrm{W}$, and $\mathrm{SO}_{3}$ were excluded from further analysis; however, the values were retained in the tables for completeness and to show small intervals where measurements were above the noise level.

\section{Petrophysical, lithologic, mineralogic, and total organic carbon data}

In this report, petrophysical logs are plotted and described with the geochemical data where they are relevant, namely magnetic susceptibility, both measured downhole and on the recovered core, and downhole spectral gamma radiation. The acquisition method for these data and for the lithologic description, digital linescan images, color reflectance, and mineralogic and total organic carbon (TOC) measurements are described in the Expedition 313 "Methods" chapter (Expedition 313 Scientists, 2010b).

\section{Statistical analyses}

For this study, 33 elements were analyzed for XRFsample measurements and 14 elements were analyzed for XRF-core measurements. Statistical analyses are extremely beneficial for identifying or corroborating trends in geochemical data, especially for larger geochemical data sets. However, geochemical data represent a compositional data set (e.g., the major oxides are summed to $100 \%$ ) and therefore suffers from the closure effect, so caution needs to be applied in the selection of appropriate statistical techniques (Aitchison, 1986; Pearson 1897; Chayes, 1960). Classical correlation plots for such constrained data can result in spurious artificial correlations, and a more applicable technique is to present correlations as a log-ratio variation matrix, a log-ratio covariance matrix, or a centered log-ratio covariance matrix (Rollinson, 1992). In this report, correlation matrixes for the quantitative XRF-sample data have been constructed based on centered log-ratios for Holes M0027A, M0028A, and M0029A (left panels in Fig. F2). The diagonal of the correlation plot shows each major element oxide and trace element against itself, with the darker the shading indicating higher the correlation (using absolute coefficient values); the nature of the correlations can be seen clearly irrespective of the reader's familiarity with the precise statistical technique.

The statistical evaluation of the data was enhanced by running a principal component analysis (PCA) for major element oxides and trace elements, again using centered log-ratios. This analysis transforms the data into orthogonal components and represents a way of reducing dimensionality. Plots of the first two principal components (PC1 and PC2) are shown for
Holes M0027A, M0028A, and M0029A (right panels in Fig. F2). Elements that are grouped together on these plots can be inferred to have a higher probability of being located within the same mineral or to be affected by similar processes.

The statistical results shown in Figure F2 are included at a larger scale in Figures DF1, DF2, and DF3 in "Appendix D," with tables of the numerical values for the first 11 principal component values in each hole in Figures DF4, DF5, and DF6.

Each site was treated as a distinct and complete data set; therefore, the interpretation needs to take into consideration the different sampling intervals and intensities in each hole, as well as the range of lithologies encountered. As such, the results should be viewed as an initial pass that is beneficial for identifying key trends rather than a rigorous analysis for a more sophisticated interpretation. More advanced analyses could divide the data by lithology and focus on selected intervals. For example, PCA run on a smaller zone would be anticipated to show more distinct groupings.

XRF-core measurements are semiquantitative. To partially account for the various factors that can affect elemental counts, raw values are routinely divided by the total counts at each measurement point and therefore also represent compositional data. Statistical analyses have not been performed on this data set because preference was given to the quantitative XRF-sample data, but elements were analyzed for correlation with the XRF-sample measurements for $\mathrm{Ba}, \mathrm{Rb}, \mathrm{Sr}, \mathrm{Zr}, \mathrm{Pb}, \mathrm{Al}, \mathrm{Si}, \mathrm{P}, \mathrm{S}, \mathrm{K}, \mathrm{Ca}, \mathrm{Ti}, \mathrm{Mn}$, and Fe, indicating a good correlation throughout and enabling future calibration of some of this data set for use as quantitative data.

\section{Results}

To facilitate the description and discussion in this report, a selection of key elements, elemental ratios, and petrophysical logs are plotted downhole for each site. The analyzed interval is divided into zones (Fig. F3). Downhole plots summarizing the complete set of XRF measurements are shown in "Appendix B" (Figs. BF1, BF2, BF3 for XRF-sample measurements).

\section{Hole M0027A}

The $63 \mathrm{~m}$ interval analyzed in Hole M0027A (238174 m CSF-B; Fig. F3A) ranges upward from clay at the base (Zone $\mathrm{K}$ ) through a series of alternating sands, silts, and clays (from Zone J to Zone $\mathrm{H}$ ) before a final sand-silt-silty clay sequence (Zone G) followed by a longer interval of clay between 208 and 
192 m CSF-B (from Zone $\mathrm{F}$ to Zone $\mathrm{C}$ ). Above this clay interval is an interval of poor recovery (10\%) with thin clays (Zone B) succeeded by sands and clays shallower than $180 \mathrm{~m}$ CSF-B (Zone A). The middle section (Zones $\mathrm{C}-\mathrm{G}$ ) have been densely sampled for XRF-sample measurements (66 of 118 samples), enabling high-resolution pattern recognition.

From the base of the analyzed interval, the change from Zone K (clay) to Zone J (sand) corresponds with a increase in $\mathrm{Si} / \mathrm{Al}$ and $\mathrm{Zr} / \mathrm{Rb}$ ratios and a decrease in Th across the boundary. The sands of Zone J display the highest $\mathrm{Si} / \mathrm{Al}$ ratios. There are several magnetic susceptibility peaks in Zone $\mathrm{J}$, but the resolution of the geochemical measurements makes it difficult to establish the nature of any correlation with Fe. At the top of Zone J, a sample with very high $\mathrm{SiO}_{2}$ correlates with a clean, coarse sand. Zone I has less data because of low recovery, but the spectral gamma ray downhole logs show a decrease consistent with a sandier lithology. Zone $\mathrm{H}$ has a series of fining- upward cycles from sands to clays that are reflected in $\mathrm{Si} / \mathrm{Al}$ and $\mathrm{Rb} / \mathrm{Zr}$ ratios and $\mathrm{Th}$ values. Zone $\mathrm{G}$ is marked by another fining-upward cycle as well as increased Mo, U, V, and Sr. At the upper limit of this zone is a large spike in $\mathrm{P}$, which is evident in both the XRF-core and XRF-sample measurements. The narrow Zone $\mathrm{F}$ is defined by a significant increase in magnetic susceptibility and $\mathrm{Fe} / \mathrm{S}$ ratios before a further increase into Zone E.

Zone $\mathrm{E}$ is characterized by considerable variability in a number of elements, including $\mathrm{Fe}, \mathrm{Mn}, \mathrm{Mg}$, As, Co, and $\mathrm{Ni}$. Although this may be in part because this zone is the most densely sampled for XRF-sample measurements, the equivalent variability in the continuous core measurements (e.g., $\mathrm{Fe} / \mathrm{S}$ ratios) and the downhole magnetic susceptibility log along with observed banding in the clays suggests this variability is not purely a function of the higher sampling density. A few peaks in As and Co coincide with magnetic susceptibility highs.

Above, in Zone D, magnetic susceptibility, Fe, and $\mathrm{Fe} / \mathrm{S}$ ratios remain high but are noticeably less variable and are followed by significant decreases in Zone C. Sr increases across this zone. The limited core recovery in Zones B and A make observations more difficult, but $\mathrm{Si} / \mathrm{Al}$ and $\mathrm{Zr} / \mathrm{Rb}$ ratios are low in the recovered clays of Zone $\mathrm{B}$ and high in the sands of Zone $\mathrm{A}$. Fe/S ratios are high in these clays and increase more in comparison to underlying zones than magnetic susceptibility, but the lower sampling resolution makes it harder to precisely identify trends.

\section{Hole M0028A}

In Hole M0028A, a shorter interval (26 m; 254-223 $m$ CSF-B; Fig. F3B) was analyzed than in Hole M0027A, beginning with a fining-upward sequence from sand to silt and clay (Zone G) overlain by a coarse sand in a lower recovery sandier interval (Zone F). The remainder of the analyzed interval is composed of a clay succession between 244 and 223 $\mathrm{m}$ CSF-B (from Zone E to Zone A). XRF-sample measurement sampling density is fairly consistent throughout the clays, and XRF-core measurements were taken on all suitable cores.

In Zones $\mathrm{H}, \mathrm{G}$, and $\mathrm{F}$, the low resolution of XRF-sample measurements combined with no XRF-core measurements from the sand and silt cores makes trends harder to identify, although there is some variability apparent in $\mathrm{Mo}$, As, Ce, and $\mathrm{Si} / \mathrm{Al}$ ratios. In Zone $\mathrm{F}$, $\mathrm{Si} / \mathrm{Al}$ ratios are higher and $\mathrm{Sr}$ is high. Magnetic susceptibility is low throughout Zones H-F.

In Zone $\mathrm{E}, \mathrm{Si} / \mathrm{Al}$ ratios are low and $\mathrm{Th}$ increases in the clay. Magnetic susceptibility suddenly increases significantly and is variable throughout the zone, with low apparent correlation with Fe when studied at higher resolution. Fe/S ratios display similar variability, and there are some depths where higher As is observed. Mo is higher in this zone.

In Zone D, magnetic susceptibility decreases, although some variability remains. One significant spike matches a spike in $\mathrm{Fe} / \mathrm{S}$ ratio. Magnetic susceptibility correlates very well with Fe in Zone D and the overlying zones. There are minor increases in $\mathrm{P}$ in this zone. The upper boundary with Zone $\mathrm{C}$ is marked by a change in $\mathrm{Fe} / \mathrm{S}$ ratios to an interval of significantly lower variability. A larger P spike occurs in this zone. $\mathrm{Zr} / \mathrm{Rb}$ ratios and, to a lesser extent, $\mathrm{Th}$ and $\mathrm{Si} / \mathrm{Al}$ ratios increase slightly and are more variable. High As content is observed in one XRF-sample measurement. Zone B is marked by a return to more variable $\mathrm{Fe} / \mathrm{S}$ ratios. Ce decreases midway through this zone. $\mathrm{Zr} / \mathrm{Rb}$ ratios are slightly higher and more variable. The base of Zone A is marked by a spike in $\mathrm{Si} / \mathrm{Al}$ and $\mathrm{Zr} / \mathrm{Rb}$ ratios and a decrease in $\mathrm{Fe}$, although it is otherwise fairly indistinguishable geochemically from the underlying zone.

\section{Hole M0029A}

In Hole M0029A, a greater depth interval (153 m; 479-326 m CSF-B; Fig. F3C) was analyzed than in the more proximal sites. The interval is characterized by sands alternating with thin silts at the base (Zone J) succeeded by a silty sequence with occasional thin 
sands (Zone I), clays, silts, and thin sands (Zones $\mathrm{H}-$ C) before reencountering sandier lithologies near the top of the interval (Zones B and A). In general, silts and silty clays predominate. Continuous intervals of clay are found between 417 and $404 \mathrm{~m}$ CSF-B (Zones $\mathrm{H}$ and $\mathrm{G}$ ) and between 399 and $387 \mathrm{~m}$ CSF-B (Zone $\mathrm{E})$, as well as shorter sections in the upper $15 \mathrm{~m}$ of the interval (in Zones B and A). The density of XRFsample measurements is reduced in the lower part of the analyzed interval (Zones J and I) and in the sandier lithologies shallower than $360 \mathrm{~m}$ (Zones B and A). XRF-core measurements were restricted to a single clay core at $344 \mathrm{~m}$ CSF-B (across the Zone B/A boundary), which is inferred to either include the seismic reflector m4.1 surface (see the "Site M0029" chapter [Expedition 313 Scientists, 2010e]) or be located immediately above (Miller et al., 2013).

The base of the analyzed interval in Hole M0029A is marked by a sample from the basal silt with high alkali content and correspondingly lower $\mathrm{Si} / \mathrm{Al}$ and $\mathrm{Zr} /$ $\mathrm{Rb}$ ratios than the overlying sands, although the low resolution of XRF-samples in Zones K-I make it difficult to interpret detailed trends. A peak in Fe that correlates with $\mathrm{P}$ and magnetic susceptibility peaks identified in both downhole logging and core data) occurs within the silts of Zone I (448 m CSF-B). This peak also corresponds to a cemented layer in the sediments (see the "Site M0029" chapter [Expedition 313 Scientists, 2010e]). In Hole M0029A, parts of the metal core catchers were noted in almost one out of two cores in the analyzed section, so the core magnetic susceptibility must be interpreted with caution (black bars across the magnetic susceptibility track in Fig. F3C). However, where variation can be corroborated by the downhole magnetic susceptibility log (acquired deeper than $404 \mathrm{~m} \mathrm{CSF-B),} \mathrm{the} \mathrm{trends} \mathrm{can}$ be established with more confidence, but they are notable for generally low values and lack of variability.

The deepest occurrence of clays in the studied interval is in Zone $\mathrm{H}$, where $\mathrm{Si} / \mathrm{Al}$ ratios increase, alkali elements decrease, and a small peak in Mo and high TOC occurs. Above Zone H, Zones G-D are relatively geochemically homogeneous, although the average sample resolution of one XRF-sample measurement per $1.5 \mathrm{~m}$, with no corroboration from XRF-core measurements, needs to be considered. Significant observations from these zones include an interval with high P and Mo (Zone G), an extremely geochemically consistent interval (Zone F), a slight decrease in $\mathrm{Zr} / \mathrm{Rb}$ ratios and corresponding increase in the Th $\log$ (Zone E), another P peak, and gradually increasing $\mathrm{U}$ uphole (Zone $\mathrm{D}$ ). The changes between clays and silts are rarely coupled with major geochemical changes.
Zone $\mathrm{C}$ is marked by an increase in alkali elements from the underlying zone and a small increase in $\mathrm{Si}$ / $\mathrm{Al}$ and $\mathrm{Zr} / \mathrm{Rb}$ ratios. This zone is characterized by more variability in $\mathrm{P}, \mathrm{Fe}$, and Mo than in the underlying zones. Zone B has lower alkali content (although note the reduced XRF-sample resolution), particularly in one sample near the top, and an increase in $\mathrm{Si} / \mathrm{Al}$ and $\mathrm{Zr} / \mathrm{Rb}$ ratios, albeit with differential increases between these ratios in different samples. Mo content is higher at the base of this zone. The change from Zone $\mathrm{B}$ to Zone $\mathrm{A}$ is marked by a decrease in $\mathrm{Si} / \mathrm{Al}$ and $\mathrm{Zr} / \mathrm{Rb}$ ratios, an increase in alkali elements, and a small rise in P. Changes across the boundary are supported by XRF-core measurement data. The remainder of Zone A has low Si/Al and $\mathrm{Rb} / \mathrm{Zr}$ ratios, high alkali content, some magnetic susceptibility and Fe variation, and gradually increasing As with higher Ce than in the underlying succession.

\section{General observations and correlations}

The correlation matrixes of XRF-sample measurements of major element oxides and trace elements show that there are some similar correlations across Holes M0027A, M0028A, and M0029A (left panels in Fig. F2). In particular, Si has a high covarying correlation (>0.75) with $\mathrm{Al}, \mathrm{K}, \mathrm{LOI}$, and $\mathrm{Fe}$ (red squares over element names in Figure F2). Rare earth elements $\mathrm{Ce}, \mathrm{La}, \mathrm{Nd}, \mathrm{Sc}$, and Y (green squares over element names in Fig. F2) are highly correlated in Holes M0027A and M0028A ( $>0.8)$ and moderately ( $>0.6)$ to highly correlated $(>0.9)$ in Hole M0029A. In all three holes, these elements are moderately to highly correlated with $\mathrm{Th}, \mathrm{V}, \mathrm{Ga}$, and $\mathrm{Ba}$ (pale green squares over element names in Fig. F2). Elements and oxides that have lower correlations (lighter shading on matrix plots, typically $<0.4$ ) are $\mathrm{Mo}, \mathrm{P}, \mathrm{U}, \mathrm{Ca}, \mathrm{Na}$ and $\mathrm{Sr}$ (blue squares over element names, Fig. F2).

In Hole M0028A, the sampled sequence was predominantly clay (all but 6 of 21 samples), which results in some different characteristics to the correlations between elements. The correlation matrix shows a general delineation between high to very high correlations among many of the trace elements (Fig. F2B) but with generally low correlations between these and the major element oxides. Correlations among the major elements oxides are similar to the other holes. In Hole M0029A,correlations are typically lower between elements, reflecting the greater range of sampled lithologies.

PCA for Holes M0027A, M0028A, and M0029A (left panels in Fig. F2) indicates that much of the variance in the data is carried by the first principal component (PC1), which is comprised of a large number of 
elements. However, because PC1 is composed of a fairly even distribution of a number of the elements studied, this does not lead to a simple interpretation, although it likely reflects a detrital component to the signature of most elements. The second principal component (PC2) in both Holes M0027A and M0029A has a grouping of major element oxides and trace elements that include $\mathrm{CaO}, \mathrm{P}_{2} \mathrm{O}_{5}, \mathrm{Sr}$, and $\mathrm{Na}_{2} \mathrm{O}$, with a slight difference in Hole M0028A where, in addition to $\mathrm{Na}_{2} \mathrm{O}$ and $\mathrm{P}_{2} \mathrm{O}_{5}$, this grouping also includes As and $U$ (purple shaded areas in Fig. F2). PCA clearly shows the clustering of rare earth elements, which are all toward the top of PC1 and near the middle of PC2 (green shaded areas in Fig. F2). In Hole M0028A, the fact that the analyzed sediment is predominantly clay produces an additional grouping of the major element oxides, including $\mathrm{Fe}_{2} \mathrm{O}_{3}$ and $\mathrm{Al}_{2} \mathrm{O}_{3}$ (brown shaded area in Fig. F2B).

\section{Clay sequences}

The clay sequences contain much of the petrophysical and geochemical variations observed in the analyzed successions but also include intervals that are extremely homogeneous.

In the clays observed in the two proximal holes (Zone E in Holes M0027A and M0028A), which is distinctive for its high, variable magnetic susceptibility, geochemical data, in particular $\mathrm{Fe} / \mathrm{S}$ ratios, indicate that although the degree of variation is similar, the magnetization and geochemical signal are responding equivalently to the characteristics of the sediment. In Hole M0027A (Fig. F4A) light and dark bands are very clear in these clays, and it is apparent that the darker bands display higher magnetic susceptibility and the lighter bands show peaks in Fe/S ratios in combination with high $\mathrm{Fe}$ and $\mathrm{Mn}$, although $\mathrm{Fe} / \mathrm{Mn}$ ratios (not shown) are near constant. $\mathrm{Si} / \mathrm{Al}$ ratios show limited variation even at very fine scales.

There are also intervals of clays that display high but more constant magnetic susceptibility where, in general, magnetic susceptibility and $\mathrm{Fe}$ have similar trends. In Hole M0028A (Fig. F4B), clays overlying the interval of highest magnetic susceptibility (Zone D) contains two nodules that display an increase in magnetic susceptibility, Fe, P, and, to a lesser extent, $\mathrm{Si} / \mathrm{Al}$ ratios. This interval also correlates with an impedance contrast and is noted to be more indurated (Fig. F3B).

Other clays, in particular in Hole M0029A, are more geochemically homogeneous. For example, in Hole M0029A (Fig. F4C) an interval of silt changing to a very homogeneous clay occurs near the top of the analyzed interval (Zone B/A boundary) in the vicin- ity of the seismic reflector m4.1 boundary. Other than the clear change observed in most geochemical data as the lithology changes from silty at the base to clay just just shallower than $343 \mathrm{~m}$ CSF-B, this clay is sedimentologically and geochemically homogeneous.

\section{Discussion and correlation across sites}

Although XRF classification schemes for sedimentary rocks are less rigorously defined than for igneous formations (e.g., Taylor and McClennan, 1985; Rollinson, 2014), there are a number of long established principles, such as the response of $\mathrm{Si} / \mathrm{Al}$ ratios to the clay (hydrodynamically light) versus quartz (hydrodynamically heavy) ratio and its use as a grain size indicator (e.g., Pettijohn et al., 1972; Potter, 1978). $\mathrm{Zr} / \mathrm{Rb}$ ratios (e.g., Dypvik et al., 2001) and downhole spectral gamma radiation content (notably Th for clay; e.g., Rider, 1996) are widely accepted to be useful as grain size indicators in many circumstances. In general, there is a correlation in all three holes between $\mathrm{Si} / \mathrm{Al}$ ratios, $\mathrm{Zr}, \mathrm{Rb}$, and $\mathrm{Th}$ with grain size. In both Holes M0027A (Zones H and F) and M0028A multiple series of offshore to shore-face cycles (Mountain et al., 2010) are reflected in fining-upward packages that are recognized in these ratios. In Hole M0029A, these ratios are generally lower and less variable. There are also a few instances where the "grain size" indicators do not vary equivalently. For example, in the clays of Zone E in Holes M0027A and M0028A, Th is more variable than either $\mathrm{Si} / \mathrm{Al}$ or $\mathrm{Zr} / \mathrm{Rb}$ ratios, which is reflected by poorer correlation between Si and Th in Hole M0028A where the majority of samples are from clay; Fig. F2B). In Zone B in Hole M0029A, Si/Al and $\mathrm{Zr} / \mathrm{Rb}$ ratios differ, with a notably high $\mathrm{Zr} / \mathrm{Rb}$ ratio in the mid-Zone $\mathrm{B}$ clay that is not matched by a corresponding increase in $\mathrm{Si} / \mathrm{Al}$ ratios.

Alkali content is commonly a measure of feldspar content in a sediment (e.g., Rollinson, 2014). The New Jersey sediments throughout all three holes display an enrichment in alkali in comparison with shale standards (e.g., the Post-Archean Average Shale [PAAS]; Taylor and McClennan, 1985; Fig. F3). There is a very strong correlation (>0.9) between $\mathrm{La}$ and $\mathrm{Th}$ in all three holes (Fig. F2), which is suggestive of monazite. Alkali content falls below PAAS at only a few places that often correlate with very high $\mathrm{Si}$ in coarse beach sands (e.g., at the base of Zone I in Hole M0027A) and therefore may reflect a long residence time on the seafloor where feldspar has been lost. The observed enrichment in feldspar may help infer likely source regions of the New Jersey sediments. 
Rare earth elements (REEs), of which Ce is illustrated in Figure F3, tend to be highly correlated with each other as well as with Th and V (Figs. F2; green shaded areas). These correlations can respond to the proportion of terrestrial to metalliferous sources (Murray et al., 1991). Here, because of their close correlation with alkali content, which in general covaries with $\mathrm{Si} / \mathrm{Al}$ ratios, and inference that $\mathrm{La}$ and $\mathrm{Th}$ are coexisting in feldspar, the main contribution to their signal appears to be detrital.

$P$ greatly increases in several places, notably in Hole M0027A (Zone F) but also to a lesser extent in Holes M0028A (Zones D and C) and M0029A (Zone D). In Hole M0027A (Zone F), thin section and scanning electron microscope (SEM) analysis shows a large number of bone fragments that would account for the increase (A. McGrath, pers. comm., 2016). In Hole M0028A, there are no equivalent spikes in $\mathrm{P}$, with smaller increases observed at cemented nodules (e.g., Zone D; Fig. F4B). High Sr in Hole M0028A (Zone F) correlates with observed shell beds (Mountain et al., 2010). In both Holes M0027A and M0028A, Zone $\mathrm{F}$ lies beneath the distinctive clays found in Zone E, and it is possible that these beds were formed during a transgression, which is consistent with the interpretation in Proust et al. (2018) for the formation of the shell beds in Hole M0028A.

The high and variable magnetic susceptibility in Zone E of Holes M0027A and M0028A and its covariance with $\mathrm{Fe}$ is in contrast to the successions elsewhere where $\mathrm{Fe}$ and magnetic susceptibility generally correspond. Magnetic susceptibility is higher in the darker bands, whereas $\mathrm{Fe} / \mathrm{S}$ ratios peak in the lighter bands (Fig. F3A). Nilsson et al. (2013) infer the formation of authigenic mineral greigite within this zone.

Elements and ratios classed as redox sensitive include $\mathrm{Fe}, \mathrm{Mn}, \mathrm{Ni}, \mathrm{V}, \mathrm{Mo}$, and $\mathrm{U}$, but some of these can be found in both detrital and authigenic minerals, and fully unraveling the geochemical evolution of these sediments is beyond the scope of this report. Mo has been used as an indicator of anoxia (e.g., Dahl et al., 2013). Here, Mo in the clays shows limited variability, although there is some correlation with $\mathrm{U}$ in the more proximal sites (Fig. F2A, F2B) and a moderate correlation with TOC measurements where available. Pyrite is an authigenic mineral observed within this zone (see the "Expedition 313 summary" chapter [Expedition 313 Scientists, 2010a]), which is consistent with As spikes (e.g., Zone D in Hole M0027A). The variability in elements and ratios, including $\mathrm{Fe} / \mathrm{S}, \mathrm{Ni}, \mathrm{V}, \mathrm{Cr}$, and to a lesser extent $\mathrm{Mo}$ in the clay sequence in Holes M0027A and M0028A (notably Zone E) suggests that these sediments were affected by postdepositional redox reactions. In Holes M0027A and M0028A, geochemical measurements were obtained from successions characterized by freshwater (top of interval; $183 \mathrm{~m}$ CSF-B in Hole M0027A and $225 \mathrm{~m}$ CSF-B in Hole M0028A) (Fig. F3A, F3B, Zone B; Expedition 313 Scientists, 2010a). This is in contrast to Hole M0029A, where much of the succession is characterized by saline pore water (Fig. F3C). There are also intervals of diagenetic cement within these intervals (Pierre et al., 2017; Fig. F3). The movement of freshwater through clays is likely to contribute to postdepositional geochemical changes in the clays of the two more proximal sites.

The geochemical observations discussed here can be placed within the sequence stratigraphic context of the Expedition 313 sediments. Holes M0027A and M0028A are located in the clinoform topsets. The inferred location of the seismic reflector $\mathrm{m} 4.1$ surface is placed within Zone $\mathrm{F}$ in these more proximal boreholes and likely represents a concatenated or merged transgressive surface and sequence boundary (Miller et al., 2013). This sequence boundary is suggested to correlate with Miocene isotope event Mi4 $\delta^{18} \mathrm{O}$ increase (Browning et al., 2013). In Hole M0029A, the seismic reflector $\mathrm{m} 4.1$ surface is also likely a merged transgressive surface and sequence boundary (Miller et al., 2013). Here, the sediments were deposited further offshore in deeper water with generally less geochemical variation. In the sequence from seismic reflector $\mathrm{m} 4.5$ to seismic reflector $\mathrm{m} 4.4$, there is a general shallowing before water depths deepen by $\sim 50 \mathrm{~m}$ across seismic reflector $\mathrm{m} 4.1$, more than accounted for by the glacioeustatic lowering (McCarthy et al., 2013). In general, geochemical data in conjunction with petrophysical and other observations suggest the clay sequence overlying seismic reflector m4.1 can be correlated across the two more proximal sites and were affected by similar geochemical processes. That these are not apparent in the more distal site could be explained by a potential change in source direction or by the significant sediment bypass above seismic reflector $\mathrm{m} 4.1$ noted by Karakaya (2012). By continued analysis of the geochemical story in relation to other observations, a more complete story of this interval is becoming established.

\section{Acknowledgments}

This research used samples and data from the Integrated Ocean Drilling Program (IODP). Data were acquired at the XRF Core Scanner Laboratory at MARUM-Center for Marine Environmental Sciences, University of Bremen, Germany. The authors would like to thank the Expedition 313 Scientists for useful 
discussions and the staff at the Bremen Core Repository for help with XRF measurements. The authors would like to thank A. Saunders for advice on the analysis of the discrete XRF data and Francine McCarthy for review comments that enabled this manuscript to be improved.

\section{References}

Aitchison, J., 1986. The Statistical Analysis of Compositional Data: London (Chapman \& Hall, Ltd.).

Barron, J.A., Browning, J., Sugarman, P., and Miller, K.G., 2013. Refinement of late-early and middle Miocene diatom biostratigraphy for the east coast of the United States. In Results of IODP Exp 313: The History and Impact of Sea-level Change Offshore New Jersey. Geosphere, 9(5):1286-1302. https://doi.org/10.1130/GES00864.1

Browning, J.V., Miller, K.G., Sugarman, P.J., Barron, J., McCarthy, F.M.G., Kulhanek, D.K., Katz, M.E., and Feigenson, M.D., 2013. Chronology of Eocene-Miocene sequences of the New Jersey shallow shelf: implications for regional, interregional, and global correlations. Geosphere, 9(6):1434-1456.

https//doi.org/10.1130/GES00857.1

Chayes, F., 1960. On correlation between variables of constant sum. Journal of Geophysical Research, 65(12):41854193. https://doi.org/10.1029/JZ065i012p04185

Dahl, T.W., Ruhl, M., Hammarlund, E.U., Canfield, D.E., Rosing, M.T., and Bjerrum, C.J., 2013. Tracing euxinia by molybdenum concentrations in sediments using handheld X-ray fluorescence spectroscopy (HHXRF). Chemical Geology, 360-361, 241-251. https://doi.org/ 10.1016/j.chemgeo.2013.10.022

Dypvik, H., and Harris, N.B., 2001. Geochemical facies analysis of fine-grained siliciclastics using $\mathrm{Th} / \mathrm{U}, \mathrm{Zr} / \mathrm{Rb}$ and $(\mathrm{Zr}+\mathrm{Rb}) /$ Sr ratios. Chemical Geology, 181(1-4):131146. https://doi.org/10.1016/S0009-2541(01)00278-9

Expedition 313 Scientists, 2010a. Expedition 313 summary. In Mountain, G., Proust, J.-N., McInroy, D., Cotterill, C., and the Expedition 313 Scientists, Proceedings of the Integrated Ocean Drilling Program, 313: Tokyo (Integrated Ocean Drilling Program Management International, Inc.). https://doi.org/10.2204/iodp.proc.313.101.2010

Expedition 313 Scientists, 2010b. Methods. In Mountain, G., Proust, J.-N., McInroy, D., Cotterill, C., and the Expedition 313 Scientists, Proceedings of the Integrated Ocean Drilling Program, 313: Tokyo (Integrated Ocean Drilling Program Management International, Inc.). https://doi.org/10.2204/iodp.proc.313.102.2010

Expedition 313 Scientists, 2010c. Site M0027. In Mountain, G., Proust, J.-N., McInroy, D., Cotterill, C., and the Expedition 313 Scientists, Proceedings of the Integrated Ocean Drilling Program, 313: Tokyo (Integrated Ocean Drilling Program Management International, Inc.). https://doi.org/10.2204/iodp.proc.313.103.2010

Expedition 313 Scientists, 2010d. Site M0028. In Mountain, G., Proust, J.-N., McInroy, D., Cotterill, C., and the Expedition 313 Scientists, Proceedings of the Integrated
Ocean Drilling Program, 313: Tokyo (Integrated Ocean Drilling Program Management International, Inc.). https://doi.org/10.2204/iodp.proc.313.104.2010

Expedition 313 Scientists, 2010e. Site M0029. In Mountain, G., Proust, J.-N., McInroy, D., Cotterill, C., and the Expedition 313 Scientists, Proceedings of the Integrated Ocean Drilling Program, 313: Tokyo (Integrated Ocean Drilling Program Management International, Inc.). https://doi.org/10.2204/iodp.proc.313.105.2010

Govindaraju, K., Rubeska, I., and Paukert, T., 1994. 1994 report on Zinnwaldite ZW-C analysed by ninety-two GIT-IWG member-laboratories. Geostandards and Geoanalytical Research, 18(1):1-42. https://doi.org/10.1111/ j.1751-908X.1994.tb00502.x

Imai, N., Terashima, S., Itoh, S., and Ando, A., 1995. 1994 compilation of analytical data for minor and trace elements in seventeen GSJ geochemical reference samples, "igneous rock series." Geostandards and Geoanalytical Research, 19(2):135-213. https://doi.org/10.1111/ j.1751-908X.1995.tb00158.x

Inwood, J., 2018. Data report: interpretation of cored intervals with greater than one hundred percent core recovery: IODP Expedition 313 used as an example methodology. In Mountain, G., Proust, J.-N., McInroy, D., Cotterill, C., and the Expedition 313 Scientists, Proceedings of the Integrated Ocean Drilling Program, 313: Tokyo (Integrated Ocean Drilling Program Management International, Inc.). https://doi.org/10.2204/iodp.proc.313.202.2018

Inwood, J., Lofi, J., Davies, S., Basile, C., Bjerum, C., Mountain, G., Proust, J.-N., Otsuka, H., and Valppu, H., 2013. Statistical classification of log response as an indicator of facies variation during changes in sea level: Integrated Ocean Drilling Program Expedition 313. Geosphere, 9(4):1025-1043.

https://doi.org/10.1130/GES00913.1

Jansen, J.H.F., Van der Gaast, S.J., Koster, B., and Vaars, A.J., 1998. CORTEX, a shipboard XRF-scanner for element analyses in split sediment cores. Marine Geology, 151(14):143-153. https://doi.org/10.1016/S0025-3227(98)00074-7

Karakaya, S., 2012. Quantitative seismic attribute analysis using artificial neural networks and seismic stratigraphic interpretation of lower to middle Miocene sediments offshore New Jersey [M.S. thesis]. Rutgers University, New Brunswick, NJ. https://rucore.libraries.rutgers.edu/rutgers-lib/39123/

Katz, M.E., Browning, J.V., Miller, K.G., Monteverde, D.H., Mountain, G.S., and WIlliams, R.H., 2013. Paleobathymetry and sequence stratigraphic interpretations from benthic foraminifera: insights on New Jersey shelf architecture, IODP Expedition 313. Geosphere, 9(6):1488-1513. https://doi.org/10.1130/GES00872.1

Kotthoff, U., Greenwood, D.R., McCarthy, F.M.G., MüllerNavarra, K., Prader, S., and Hesselbo, S.P., 2014. Late Eocene to middle Miocene (33 to 13 million years ago) vegetation and climate development on the North American Atlantic Coastal Plain (IODP Expedition 313, Site M0027). Climate of the Past, 10:1523-1539. https://doi.org/10.5194/cp-10-1523-2014 
Kuhlmann, H., Freudenthal, T., Helmke, P., and Meggers, H., 2004. Reconstruction of paleoceanography off NW Africa during the last 40,000 years: influence of local and regional factors on sediment accumulation. Marine Geology, 207(1-4):209-224.

https://doi.org/10.1016/j.margeo.2004.03.017

Lofi, J., Inwood, J., Proust, J.-N., Monteverde, D.H., Loggia, D., Basile, C., Otsuka, H., Hayashi, T., Stadler, S., Mottl, M.J., Fehr, A., and Pezard, P.A., 2013. Fresh-water and salt-water distribution in passive margin sediments: insights from Integrated Ocean Drilling Program Expedition 313 on the New Jersey margin. Geosphere, 9(4):1009-1024. https://doi.org/10.1130/GES00855.1

Lyle, M., Olivarez Lyle, A., Gorgas, T., Holbourn, A., Westerhold, T., Hathorne, E., Kimoto, K., and Yamamoto, S., 2012. Data report: raw and normalized elemental data along the Site U1338 splice from X-ray fluorescence scanning. In Pälike, H., Lyle, M., Nishi, H., Raffi, I., Gamage, K., Klaus, A., and the Expedition 320/ 321 Scientists, Proceedings of the Integrated Ocean Drilling Program, 320/321: Tokyo (Integrated Ocean Drilling Program Management International, Inc.). https://doi.org/10.2204/iodp.proc.320321.203.2012

McCarthy, F.M.G., Katz, M.E., Kotthoff, U., Browning, J.V., Miller, K.G., Zanatta, R., Williams, R.H., Drljepan, M., Hesselbo, S.P., Bjerrum, C.J., and Mountain, G.S., 2013. Sea-level control of New Jersey margin architecture: palynological evidence from Integrated Ocean Drilling Program Expedition 313. Geosphere, 9(6):1457-1487. https://doi.org/10.1130/GES00853.1

Miller, K.G., Browning, J.V., Mountain, G.S., Bassetti, M.A., Monteverde, D., Katz, M.E., Inwood, J., Lofi, J., and Proust, J.-N., 2013. Sequence boundaries are impedance contrasts: core-seismic-log integration of OligoceneMiocene sequences, New Jersey shallow shelf. In Results of IODP Exp 313: The History and Impact of Sea-level Change Offshore New Jersey. Geosphere, 9(5):1257-1285. https://doi.org/10.1130/GES00858.1

Murray, R.W., Buchholtz Ten Brink, M.R., Gerlach, D.C., Russ, G.P., III, and Jones, D.L., 1991. Rare earth, major, and trace elements in chert from the Franciscan Complex and Monterey Group, California: assessing REE sources to fine-grained marine sediments. Geochimica et Cosmochimica Acta, 55(7):1875-1895. https://doi.org/10.1016/0016-7037(91)90030-9

Nilsson, A., Lee, Y.S., Snowball, I., and Hill, M., 2013. Magnetostratigraphic importance of secondary chemical remanent magnetizations carried by greigite $\left(\mathrm{Fe}_{3} \mathrm{~S}_{4}\right)$ in Miocene sediments, New Jersey shelf (IODP Expedition 313). Geosphere, 9(3):510-520.

https://doi.org/10.1130/GES00854.1

Pearson, K., 1897. Mathematical contributions to the theory of evolution. - On a form of spurious correlation which may arise when indices are used in the measurement of organs. Proceedings of the Royal Society of London, 60:489-497. https://doi.org/10.1098/rspl.1896.0076

Penkrot, M., LeVay, L.J., and Jaeger, J.M., 2017. Data report: X-ray florescence scanning of sediment cores, Site U1419, Gulf of Alaska. In Jaeger, J.M., Gulick, S.P.S., LeVay, L.J., and the Expedition 341 Scientists, Proceed- ings of the Integrated Ocean Drilling Program, 341: College Station, TX (Integrated Ocean Drilling Program). https://doi.org/10.2204/iodp.proc.341.203.2017

Pettijohn, F.J., Potter, P.E., and Siever, R., 1972. Sand and Sandstone: New York (Springer-Verlag). https://doi.org/ 10.1007/978-1-4615-9974-6

Pickering, K.T., Marsh, N.G., and Dickie, B., 1993. Data report: inorganic major, trace, and rare earth element analyses of the muds and mudstones from Site 808. In Hill, I.A., Taira, A., Firth, J.V., et al., Proceedings of the Ocean Drilling Program, Scientific Results, 131: College Station, TX (Ocean Drilling Program), 427-450. https://doi.org/10.2973/odp.proc.sr.131.144.1993

Pierre, C., Blanc-Valleron, M.-M., Boudouma, O., and Lofi, J., 2017. Carbonate and silicate cementation of siliciclastic sediments of the New Jersey shelf (IODP Expedition 313): relation with organic matter diagenesis and submarine groundwater discharge. Geo-Marine Letters, 37(6):537-547. https://doi.org/10.1007/s00367-017-0506-6

Potter, P.E., 1978. Petrology and chemistry of modern big river sands. The Journal of Geology, 86(4):423-449. https://www.jstor.org/stable/30060028

Proust, J.-N., Pouderoux, H., Ando, H., Hesselbo, S.P., Hodgson, D.M., Lofi, J., Rabineau, M., and Sugarman, P.J., 2018. Facies architecture of Miocene subaqueous clinothems of the New Jersey passive margin: results from IODP-ICDP Expedition 313. Geosphere, 14(4):1564-1591. https://doi.org/10.1130/GES01545.1

Rider, M.H., 1996. The Geological Interpretation of Well Logs (2nd edition): Caithness (Whittles Publishing).

Rollinson, H.R., 1992. Another look at the constant sum problem in geochemistry. Mineralogical Magazine, 56(385):469-475. https://doi.org/10.1180/minmag.1992.056.385.03

Rollinson, H.R., 2014. Using Geochemical Data: Evaluation, Presentation, Interpretation: New York (Routledge).

Rothwell, R.G., Hoogakker, B., Thomson, J., Croudace, I.W., and Frenz, M., 2006. Turbidite emplacement on the southern Balearic Abyssal Plain (western Mediterranean Sea) during Marine Isotope Stages 1-3: an application of ITRAX XRF scanning of sediment cores to lithostratigraphic analysis. In Rothwell, R.G. (Ed.), New Techniques in Sediment Core Analysis. Special Publication - Geological Society of London, 267:79-98. https://doi.org/10.1144/GSL.SP.2006.267.01.06

Tarney, J., and Marsh, N.G., 1991. Major and trace element geochemistry of Holes CY-1 and CY-4: implications for petrogenetic models. In Gibson, I.L., Malpas, J., Robinson, RT., and Xenophontos, C. (Eds.), Initial Reports of the Cyprus Crustal Study Project. Paper - Geological Survey of Canada, 90-20:133-176.

Taylor, S.R., and McLennan, S.M., 1985. The Continental Crust: Its Composition and Evolution: Oxford, UK (Blackwell Science Publishing).

Tjallingii, R., Röhl, U., Kölling, M., and Bickert, T., 2007. Influence of the water content on X-ray fluorescence core-scanning measurements in soft marine sediments. 
Geochemistry, Geophysics, Geosystems, 8(2):Q02004. https://doi.org/10.1029/2006GC001393

Türke, A., Bach, W., and Mehmood, M.S., 2014. Data report: $\mathrm{X}$-ray fluorescence scanning of sediment cores from Holes U1382B, U1383D, U1384A, and 1074A from the North Pond area. In Edwards, K.J., Bach, W., Klaus, A., and the Expedition 336 Scientists, Proceedings of the Integrated Ocean Drilling Program, 336: Tokyo (Integrated Ocean Drilling Program Management International, Inc.). https://doi.org/10.2204/iodp.proc.336.202.2014
Zachos, J.C., Dickens, G.R., and Zeebe, R.E., 2008. An early Cenozoic perspective on greenhouse warming and carbon-cycle dynamics. Nature, 451(7176):279-283. https://doi.org/10.1038/nature06588

Initial receipt: 31 January 2018

Acceptance: 24 September 2018

Publication: 23 January 2019

MS 313-203 
Figure F1. A. Location of Holes M0027A, M0028A, and M0029A in relation to the New Jersey margin. B. Overview of the analyzed intervals (red arrows) in relation to the seismic stratigraphy and sedimentological units. Note that because of the close proximity of the seismic reflectors (m4.1, m4.5, m5, and m5.2) in Hole M0027A, the seismic reflector $\mathrm{m} 4.1$ text label is positioned above the seismic reflector.

A

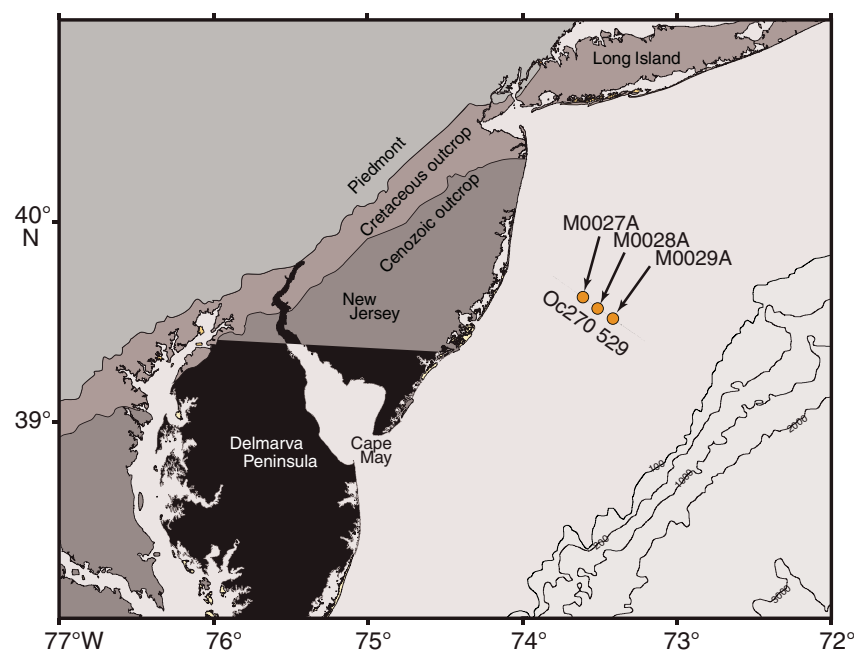

B

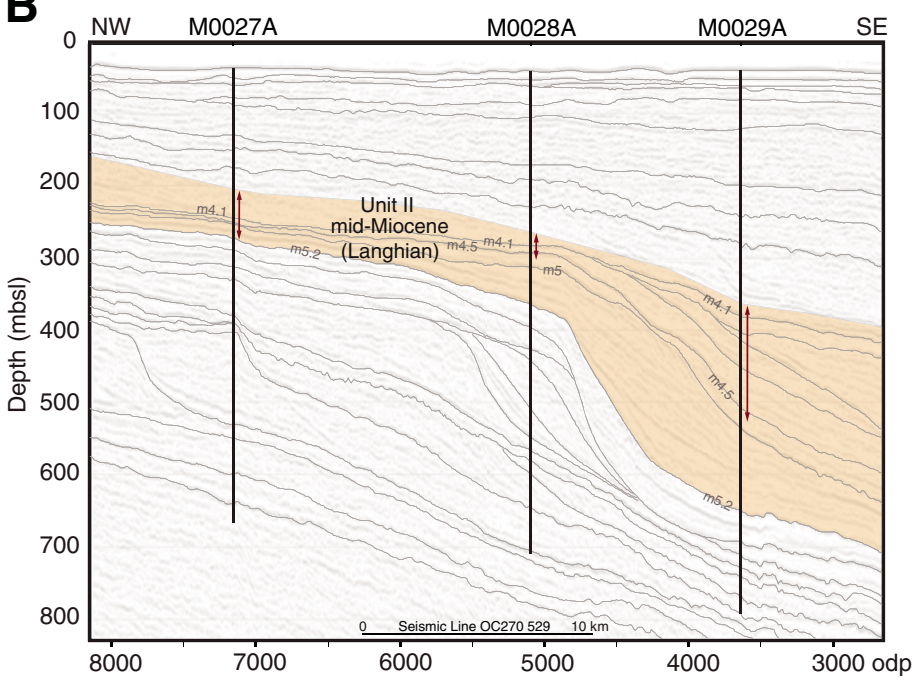


Figure F2. Statistical analyses for X-ray fluorescence (XRF)-sample data for Holes (A) M0027A, (B) M0028A, and (C) M0029A as (left) correlation plots and (right) principal component analysis (PCA) plots of the first two principal components. Correlation plots: major element oxides are listed without the oxide; green $=$ REEs, red $=$ elements with a high covarying correlations, pale green $=$ elements with moderate to high correlations, blue $=$ elements and oxides with lower correlations. PCA plots: purple shading = second principal component (PC2) element grouping, green shading = rare earth elements (REEs), brown shading = element grouping in clay. Statistical results can be seen at larger scale in "Appendix D," along with numerical values for the PCA analyses. (Figure shown on next page.) 
Figure F2 (continued). (Caption shown on previous page.)

A

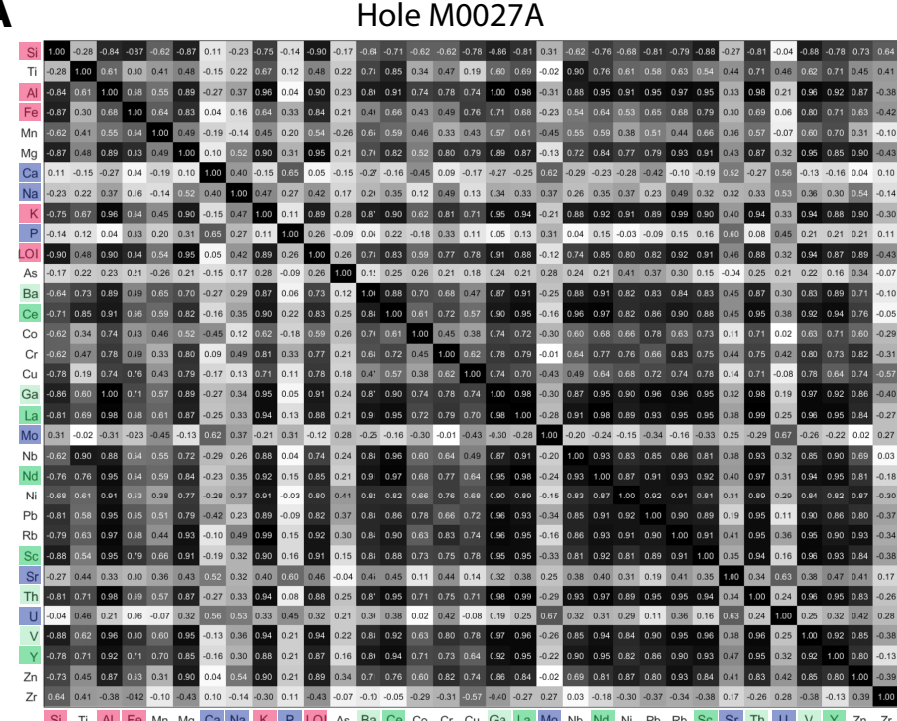

Hole M0027A

B

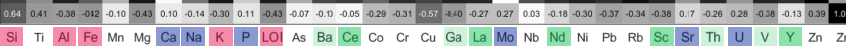

Hole M0028A

\section{C}
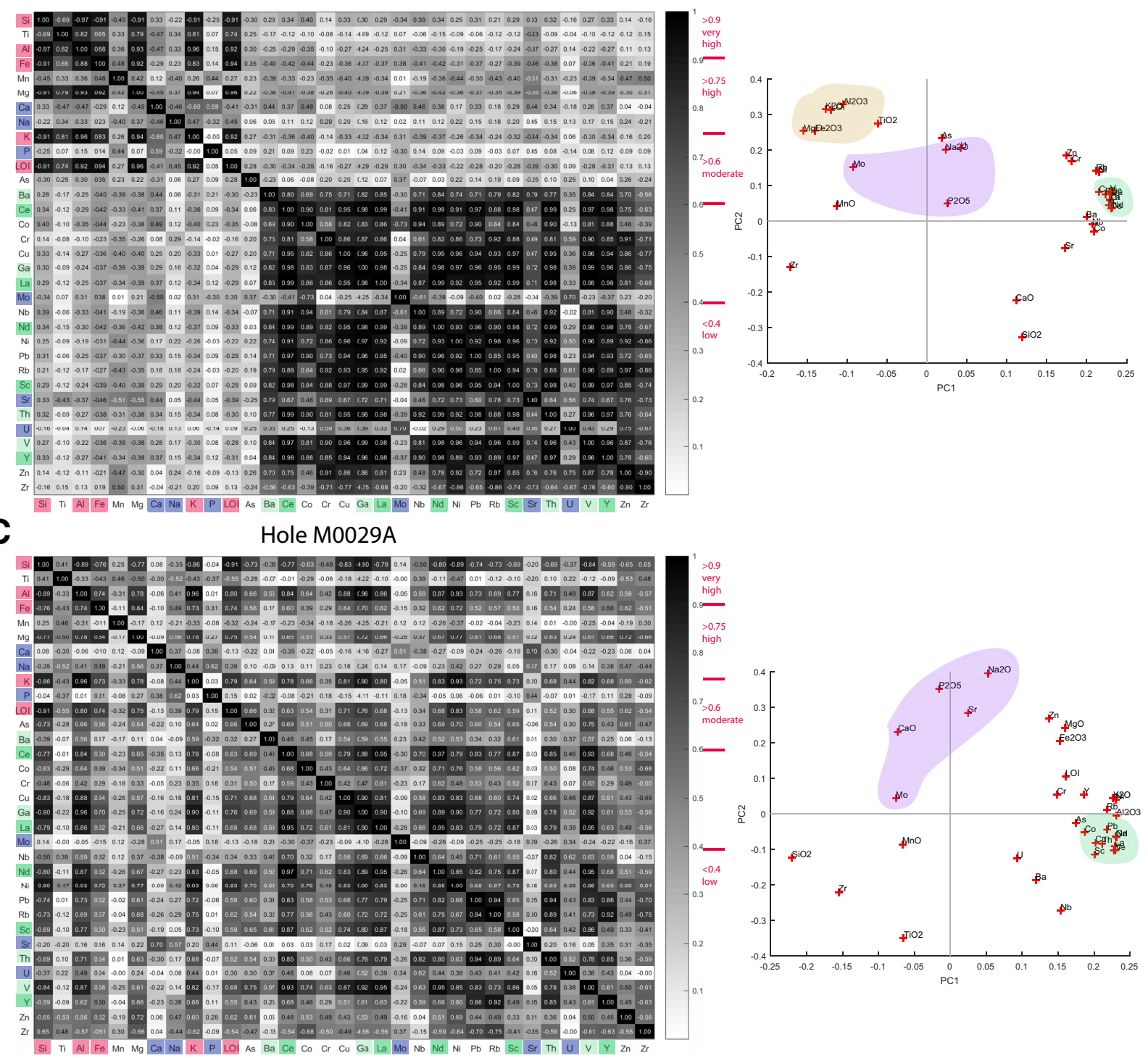
Figure F3. Selected X-ray fluorescence (XRF) major oxides and trace element data, key element ratios, and physical property logs for Holes (A) M0027A, (B) M0028A, and (C) M0029A. All measured data are shown as scaled depths (core depth below seafloor, Method B [CSF-B]) with logs depth-matched to a reference log (wireline matched depth below seafloor [WMSF]). Only core numbers are given for Hole M0029A because of the smaller scale of the plot). Black shading in section/core = overlapping intervals (excluding core catcher sections) where caution needs to be applied to the analysis of associated samples. Lithology is from the "Expedition 313 summary" chapter (Expedition 313 Scientists, 2010a) $++=$ XRF-sample data that are extrapolated by a dotted line where data from the split core surface are not available (these lines are shown as a visual guide only as where sampling intervals are lower there are large gaps between samples). Split core data have been normalized to total counts (suffixed by “_nrm") unless a ratio is used where, as measurements were taken every 1 $\mathrm{cm}$, these have been averaged and shown as a continuous line (suffixed by "_cc"). Downhole logs are shown as a heavier dashed line. Consistent scales are used across all sites, with the exception of the downhole magnetic susceptibility log in Hole M0027A where a larger maximum value was required to capture the variation. The right column of each plot indicates the location of sequence boundaries (Miller et al., 2013) and their ages, as per the base of the overlying sequence (Browning et al., 2013). Note that for seismic reflector m4.1 in Holes M0027A and M0028A the ages reflect the top of the underlying sequence (Browning et al., 2013). The location of indurated sediments (black), pore water salinity (fresh $=$ blue, saline $=$ yellow) are indicated after the "Expedition 313 summary" chapter (Expedition 313 Scientists, 2010a). The geochemical and physical property data are color-coded as below in the plots for all holes, from left to right: Orange (3 tracks): $\mathrm{Si} / \mathrm{Al}$ and $\mathrm{Zr} / \mathrm{Rb}$ ratios and Th. Note that Th has reverse scale for easier comparison with the ratios. Blue ( 2 tracks): Track 1 shows total alkali $\left[\left(\mathrm{Na}_{2} \mathrm{O}+\mathrm{K}_{2} \mathrm{O}\right) / \mathrm{K}_{2} \mathrm{O}\right]$ and the PAAS total alkali for comparison (Taylor and McClennan, 1985). $\mathrm{K}$ is plotted in Track 2 . Red $(1$ track $)=$ P. Purple $(2$ tracks $)=\mathrm{Fe} / \mathrm{S}$ ratio (core and log magnetic susceptibility and total Fe also shown). Note that for Hole M0029A intervals of high electrical resistivity are included (black bars) to show where the core magnetic susceptibility must be interpreted with caution due to repeated instances of metal core catcher fragments within the core. Brown ( 2 tracks) = Mo and U with core TOC measurements. Green ( 3 tracks) $=\mathrm{As}, \mathrm{Sr}$, and Ce with core total sulfur measurements. (Figure shown on next three pages.) 
Figure F3 (continued). (Continued on next page.) (Caption shown on previous page.)

A

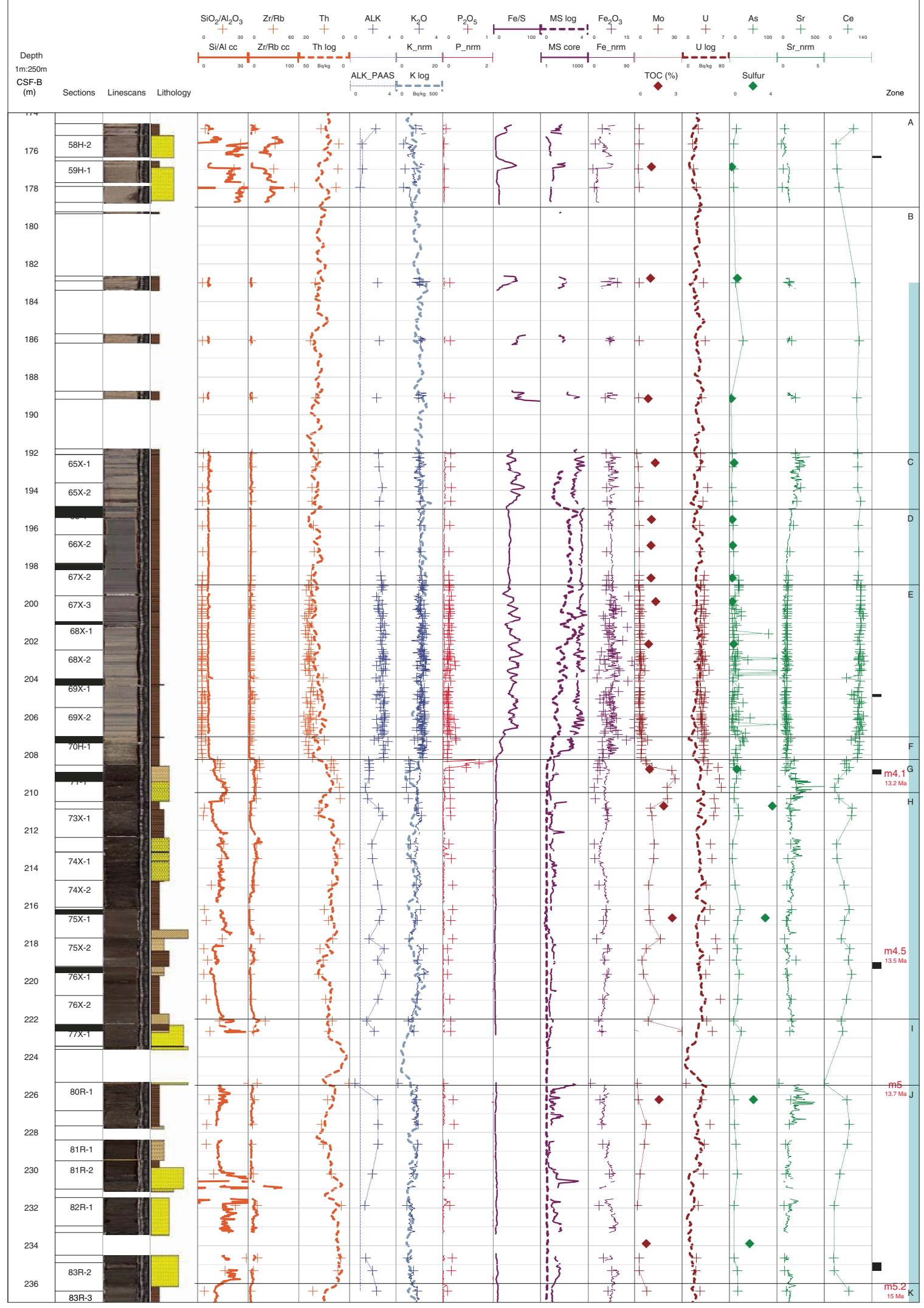


Figure F3 (continued). (Continued on next page.)

B

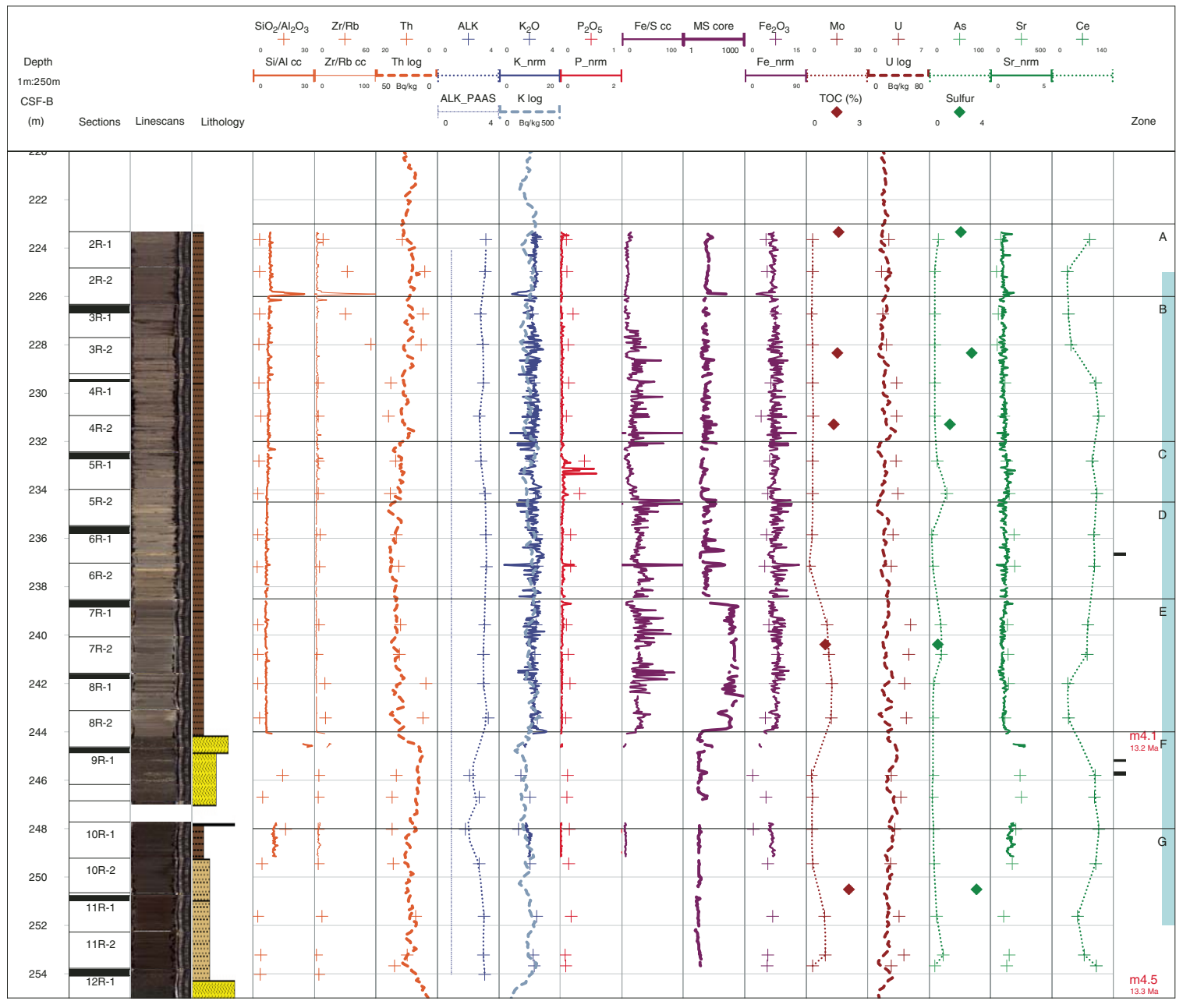


Figure F3 (continued).

C

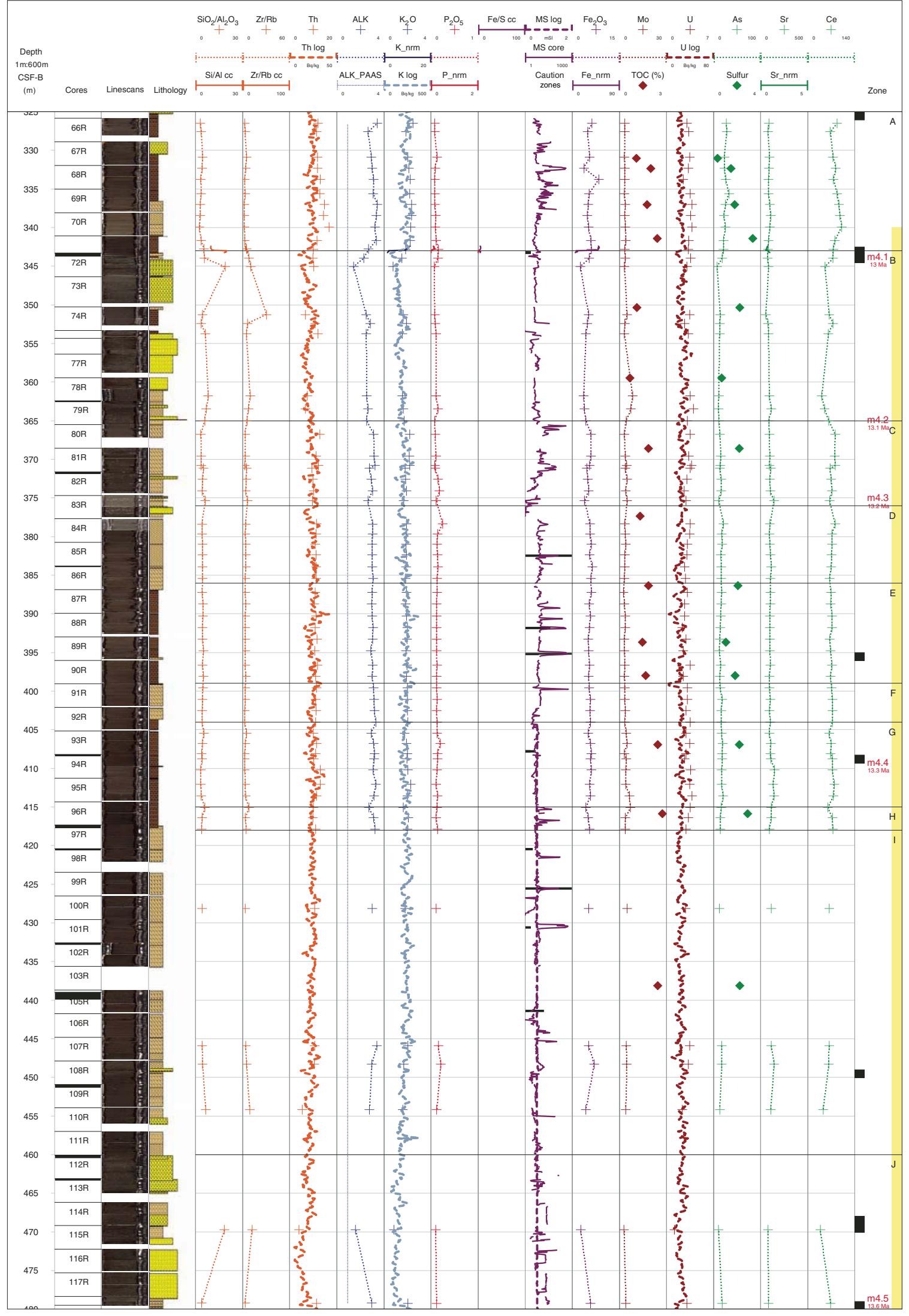


Figure F4. A. Banded clay interval with high magnetic susceptibility (Section 313-M0027A-68R-2; 202.4-203.4 $\mathrm{m}$ CSF-B). Darker bands have high magnetic susceptibility and low Fe. Si/Al ratios show no discernible pattern, suggesting little difference in grain size despite increasing the scale from Figure F2A. B. Section M0028A-6R-2 (236.4-237.4 m CSF-B). This interval is in the clays above the interval of higher magnetic susceptibility and illustrates the increase in magnetic susceptibility and Fe over a nodule. Si/Al ratios also increase, although note the change of scale from Figure F2B. C. Section M0029A-71R-2 (242.4-243.4 m CSF-B). This interval is an apparently homogeneous clay until a change to siltier lithology at $342.9 \mathrm{~m} \mathrm{CSF-B}$. The seismic reflector m4.1 surface was originally interpreted to fall within this interval (see the "Expedition 313 summary" chapter [Expedition 313 Scientists, 2010a]), but was shifted downhole postexpedition (Miller et al., 2013).
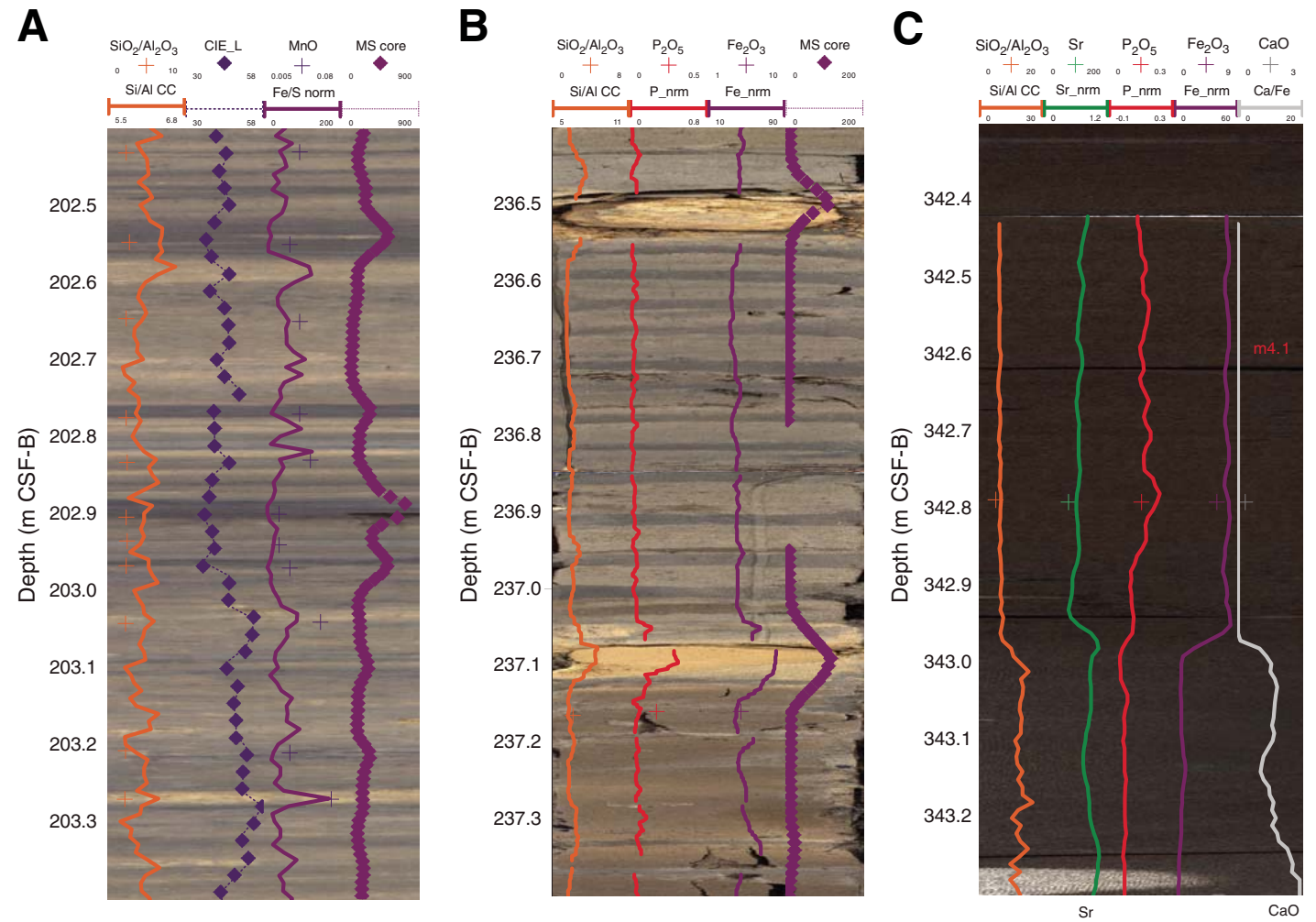
Table T1. Depth interval summaries for new X-ray fluorescence (XRF) data, relevant expedition data (see the "Expedition 313 summary" chapter [Expedition 313 Scientists, 2010a]), and updated seismic reflection surface depths (Miller et al., 2013), Holes M0027A, M0028A, and M0029A.

\begin{tabular}{|c|c|c|c|c|c|}
\hline $\begin{array}{c}\text { XRF } \\
\text { continuous core } \\
\text { (new data, this report) } \\
\text { CSF-A }(m)\end{array}$ & $\begin{array}{c}\text { XRF } \\
\text { core samples } \\
\text { (new data, this report) } \\
\text { CSF-A }(\mathrm{m})\end{array}$ & $\begin{array}{l}\text { Petrophysical downhole } \\
\text { data available through } \\
\text { the analyzed interval }\end{array}$ & $\begin{array}{c}\text { Petrophysical data on whole } \\
\text { cores and samples of interest } \\
\text { to this report }\end{array}$ & $\begin{array}{l}\text { Depth of key seismic } \\
\text { reflection surfaces } \\
\text { in measured interval } \\
\text { CSF-A }(\mathrm{m})\end{array}$ & $\begin{array}{c}\text { Lithostratigraphic } \\
\text { Unit II } \\
\text { CSF-A (m) }\end{array}$ \\
\hline \multicolumn{6}{|l|}{ Hole M0027A } \\
\hline $174.64-237.66$ & $174.84-236.53 \mathrm{~m}$ & Spectral gamma ray, & $\begin{array}{l}\text { Density, } P \text {-wave velocity, } \\
\text { magnetic susceptibility, } \\
\text { resistivity, NGR (whole } \\
\text { cores) }\end{array}$ & m4.1: 209 (70X-2/71X-1) & 167.74-236.16 \\
\hline$(58 \mathrm{H}-1$ to $83 \mathrm{R}-3)$ & $(58 \mathrm{H}-1$ to $83 \mathrm{R}-3)$ & $\begin{array}{l}\text { magnetic susceptibility, } \\
\text { electrical conductivity, } \\
\text { sonic velocity }\end{array}$ & $\begin{array}{l}\text { Digital linescans, color } \\
\text { reflectance (split core } \\
\text { surface) }\end{array}$ & $\mathrm{m} 4.5: 218.39(75 \mathrm{X}-2)$ & $(57 \mathrm{H}-2$ to $83 \mathrm{R}-2)$ \\
\hline $63 \mathrm{~m}$ interval & $62 \mathrm{~m}$ interval & & Density, velocity (samples) & $\begin{array}{l}\text { m5: } 225.45(80 R-1) \\
\text { m5.2: } 236.15(83 R-2)\end{array}$ & \\
\hline \multicolumn{6}{|l|}{ Hole M0028A } \\
\hline $223.34-249.22$ & $223.69-254.02$ & & & m4.1: 244.16 (8R-2) & $223.33-335.37$ \\
\hline $\begin{array}{l}(2 \mathrm{R}-1 \text { to } 10 \mathrm{R}-1) \\
26 \mathrm{~m} \text { interval }\end{array}$ & $\begin{array}{l}\text { (2R-1 to } 12 \mathrm{R}-1) \\
30 \mathrm{~m} \text { interval }\end{array}$ & Spectral gamma ray & As above & $\mathrm{m} 4.5: 254.23(12 \mathrm{R}-1)$ & (2R-1 to $49 \mathrm{R}-2)$ \\
\hline \multicolumn{6}{|l|}{ Hole M0029A } \\
\hline $\begin{array}{l}342.61-43.62 \\
(71 \mathrm{R}-2) \\
1 \mathrm{~m} \text { interval }\end{array}$ & $\begin{array}{l}326.48-479.25 \\
(66 \mathrm{R}-1 \text { to } 118 \mathrm{R}-1) \\
153 \mathrm{~m} \text { interval }\end{array}$ & $\begin{array}{l}\text { Spectral gamma ray } \\
\text { (throughout), magnetic } \\
\text { susceptibility, sonic } \\
\text { velocity, conductivity } \\
\text { (lower part, deeper than } \\
400 \text { m CSF-A) }\end{array}$ & As above & $\begin{array}{l}\mathrm{m} 4.1343 .81(72 \mathrm{R}-1) \\
\mathrm{m} 4.2: 364.86(79 \mathrm{R}-2) \\
\mathrm{m} 4.3: 377.15(83 \mathrm{R}-2) \\
\mathrm{m} 4.4: 409.27(94 \mathrm{R}-1) \\
\mathrm{m} 4.5: 478.61(118 \mathrm{R}-1)\end{array}$ & $\begin{array}{l}325.12-640.51 \\
(65 R-2 \text { to } 175 R-1)\end{array}$ \\
\hline
\end{tabular}

$\mathrm{NGR}=$ natural gamma radiation 


\section{Appendixes}

\section{Appendix A}

This appendix contains depth map tables for the analyzed interval in Holes M0027A and M0028A and M0029A. There is a table for each site to enable straightforward depth mapping between expedition core depths (CSF-A), expanded depths (CSF-append if long), and scaled depths (CSF-B), provided any data being analyzed is associated with its core label in identical format. See Tables AT1 (Site M0027), AT2 (M0028) and AT3 (M0029).

\section{Appendix B}

This appendix contains XRF core data normalized to total counts. Selected ratios are shown as downhole plots for Holes M0027A (Fig. BF1), M0028A (Fig. BF2), and M0029A(Fig. BF3). Data for the plots are shown in Tables BT1, BT2, and BT3. Data for elements that are deemed unreliable for publication have been removed.

\section{Appendix C}

This appendix contains XRF sample data for the major element oxides and trace elements. Data are shown downhole as plots for Holes M0027A (Fig. CF1), M0028A (Fig. CF2), and M0029A (Fig. CF3).Data for the plots are shown in Tables CT1, CT2, and CT3. Data for elements that have low concentrations or are otherwise unsuitable for analysis (that have been taken out of the downhole plots, analyses, and discussions) are indicated in the table.

\section{Appendix D}

This appendix contains statistical analyses for Holes M0027A, M0028A, and M0029A as correlation plots (Figs. DF1, DF2, DF3) and PCA analyses on XRF sample data (Figs. DF4, DF5, DF6), displaying the first 11 principal components, sorted in descending order of absolute magnitude of the first principal component and a list on the right sorted in descending order of importance to the second principal component. Below each summary table, the results are displayed as a plot of the first two principal components. For the correlation plots, major element oxides are listed omitting the oxide on the correlation plots due to space. 
Figure BF1. XRF-core downhole profile, Hole M0027A.

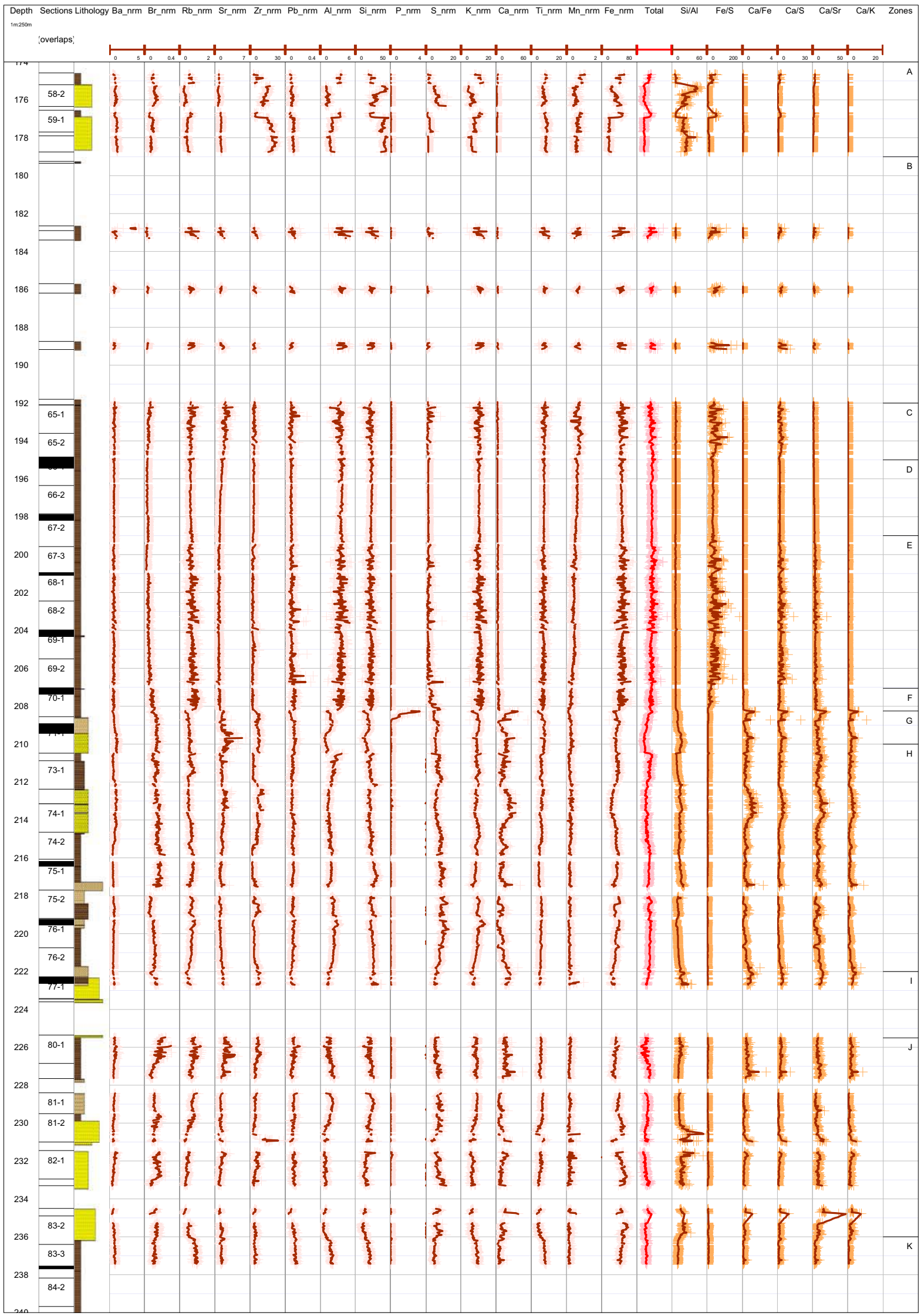


Figure BF2. XRF-core downhole profile, Hole M0028A.

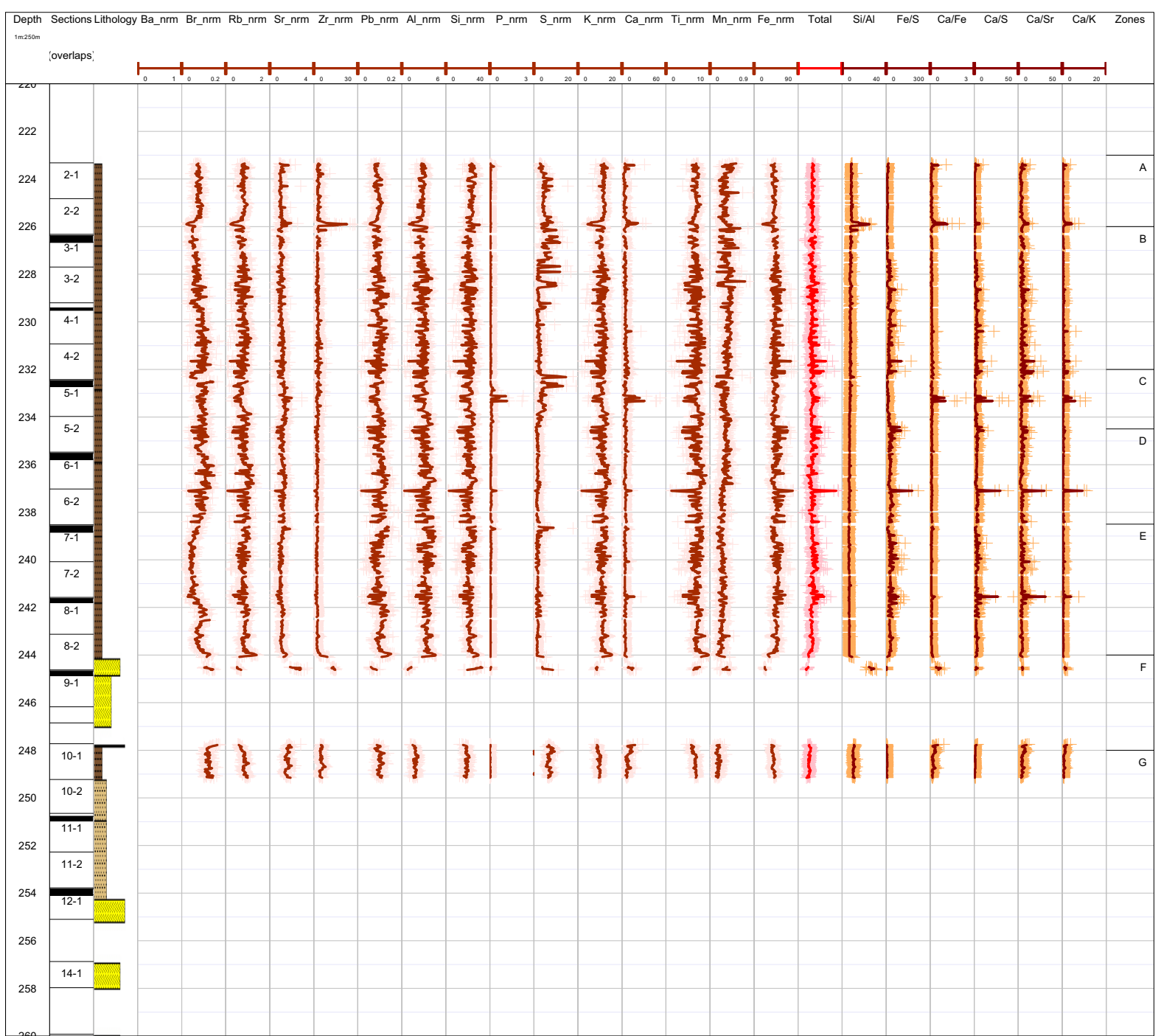


Figure BF3. XRF-core downhole profile, Hole M0029A.

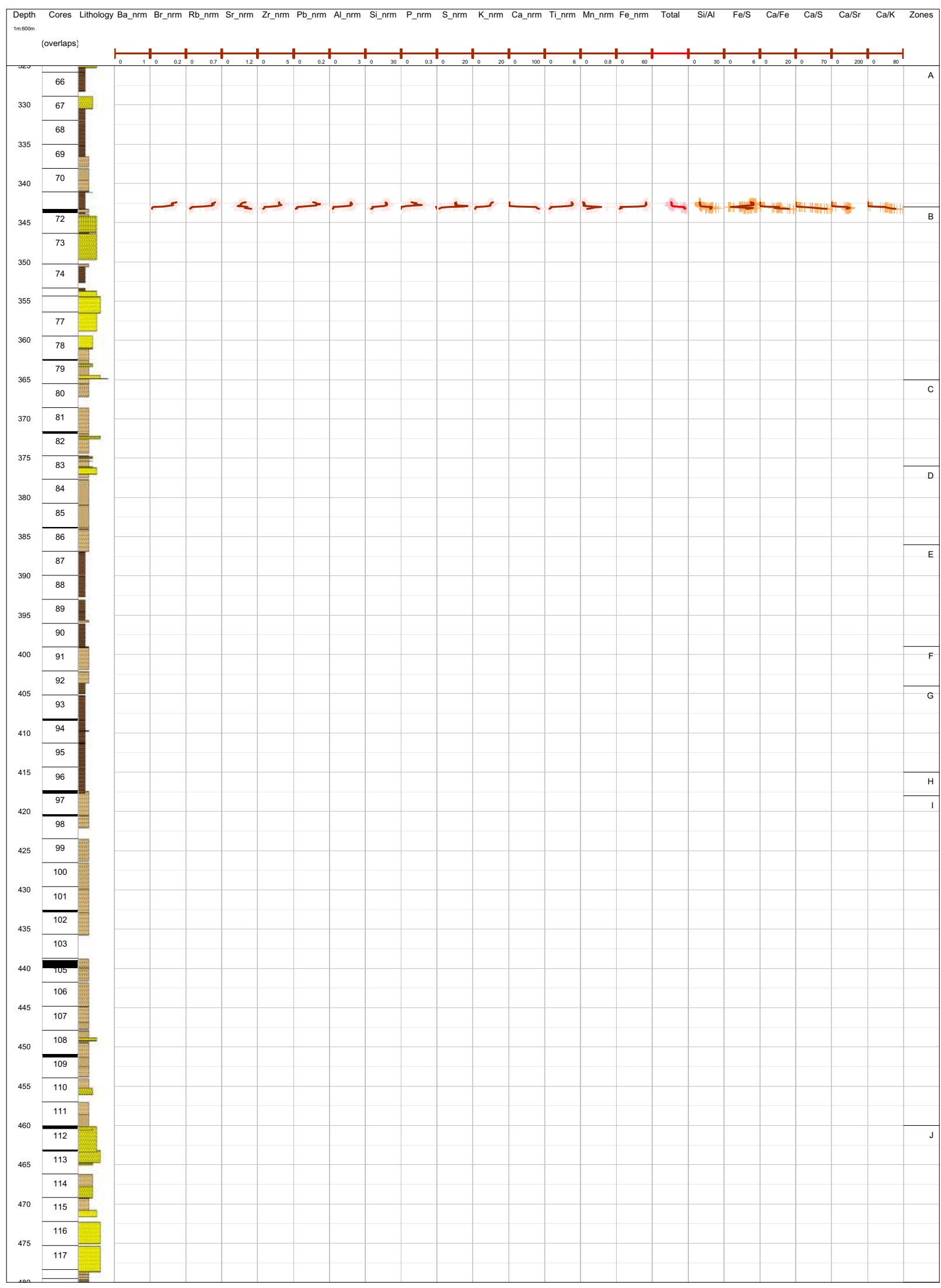


Figure CF1. XRF-sample downhole profile, Hole M0027A.

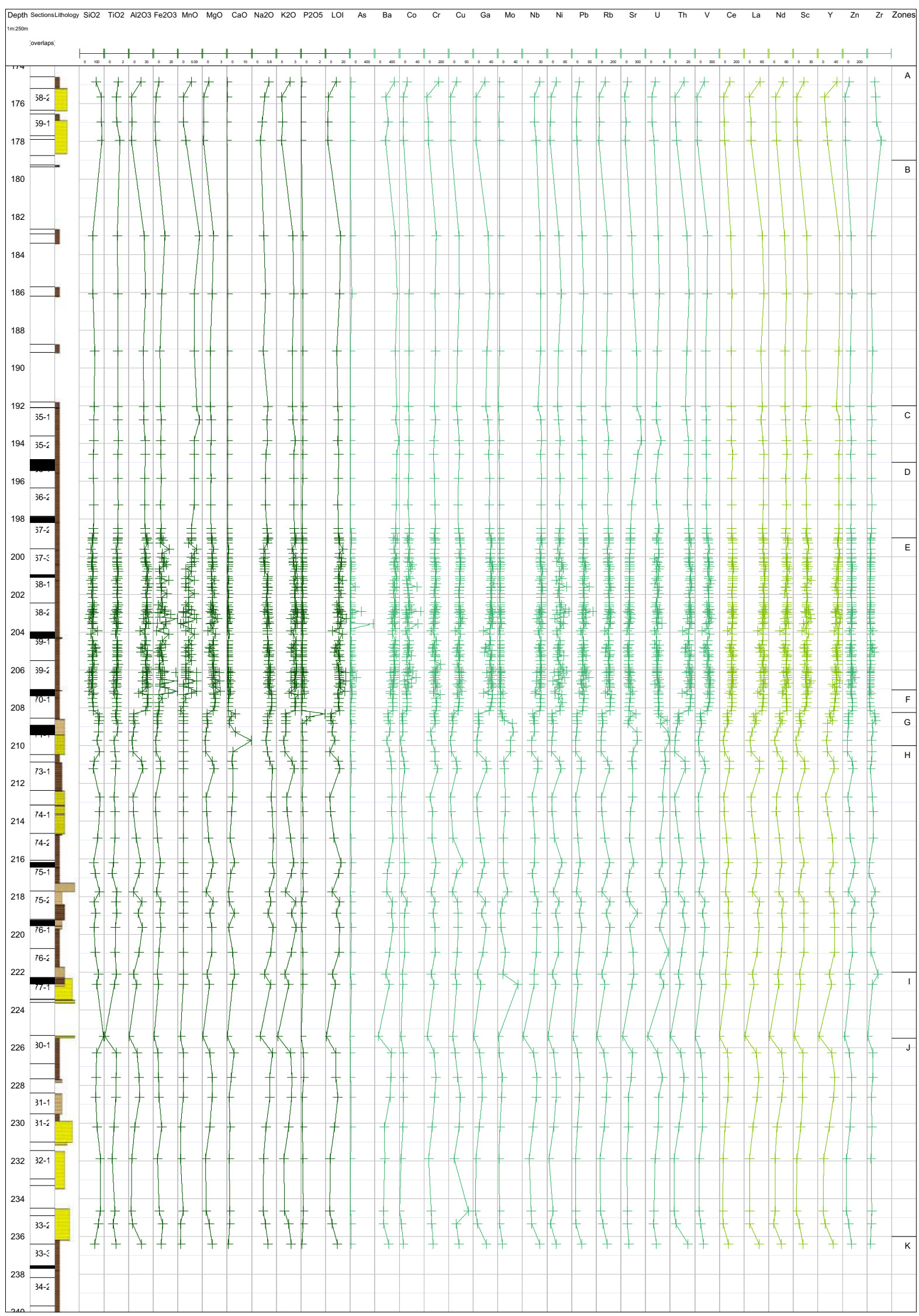


Figure CF2. XRF-sample downhole profile, Hole M0028A.

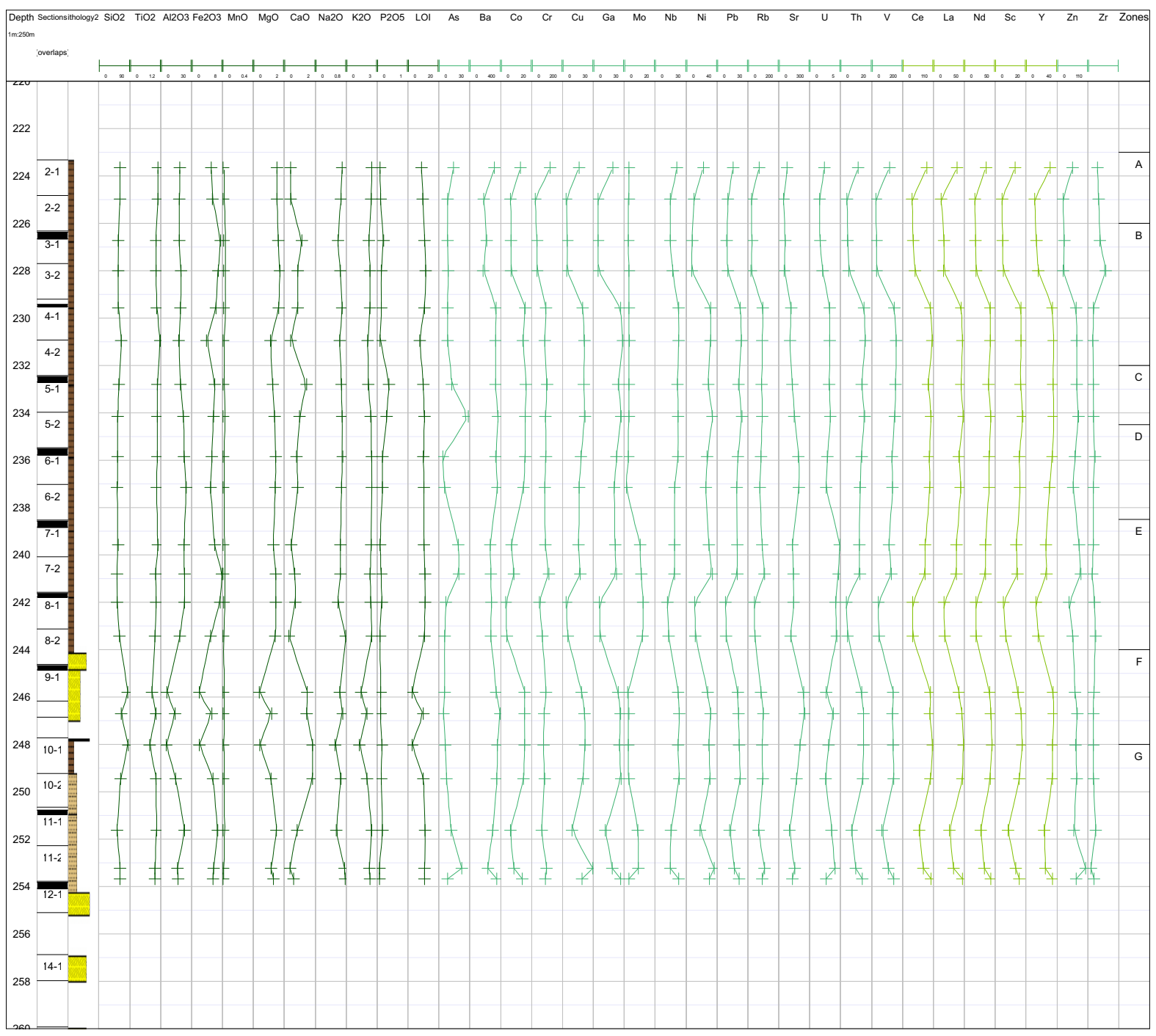


Figure CF3. XRF-sample downhole profile, Hole M0029A.

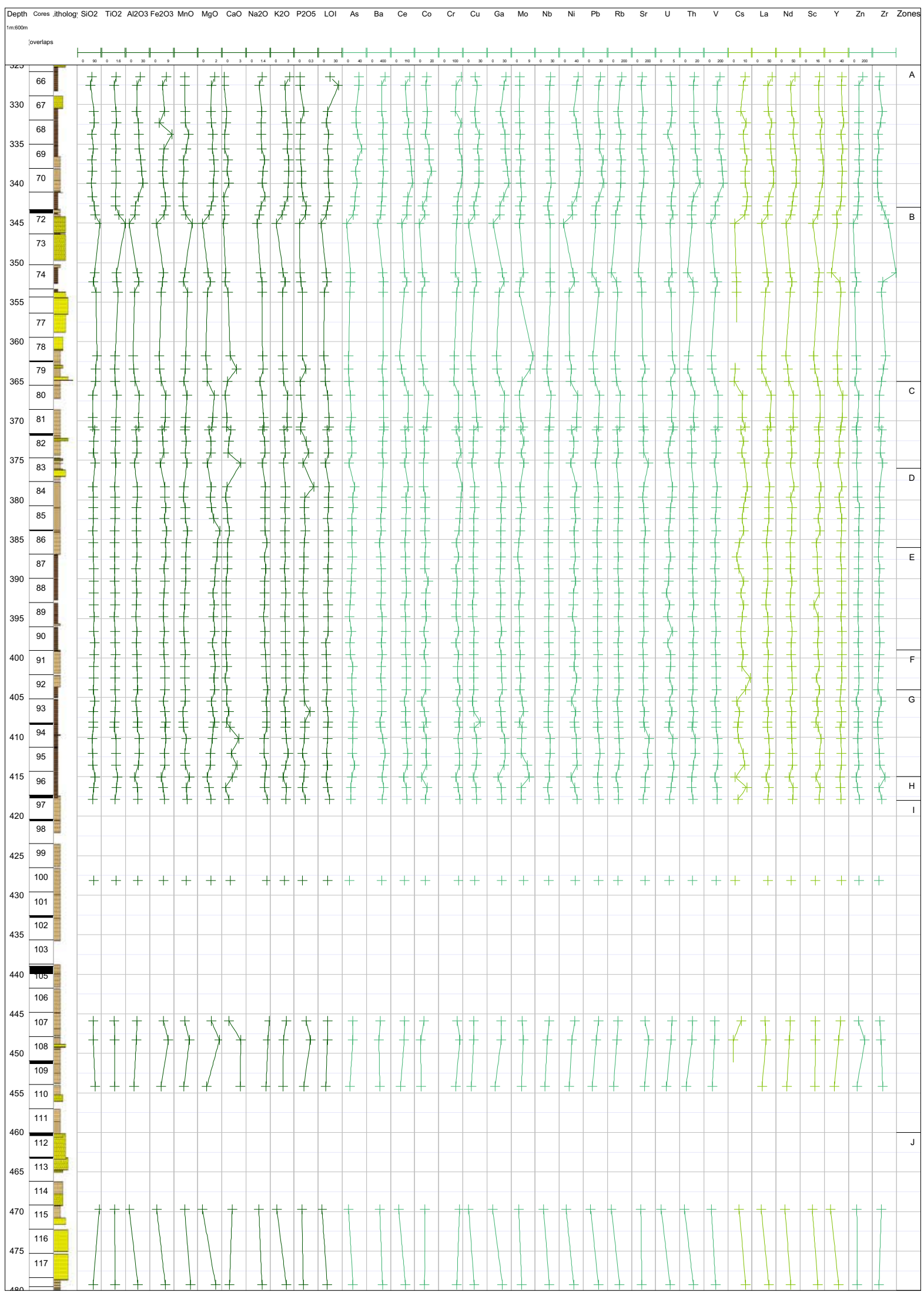


Figure DF1. PCA correlation, Hole M0027A.

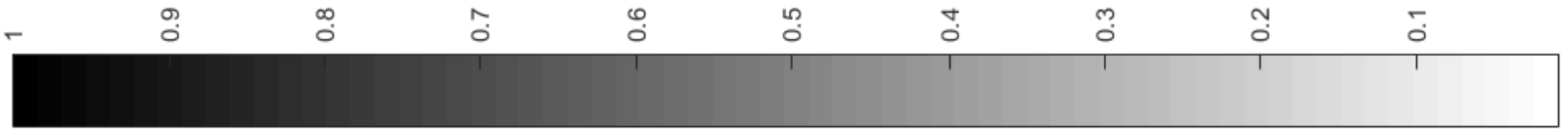

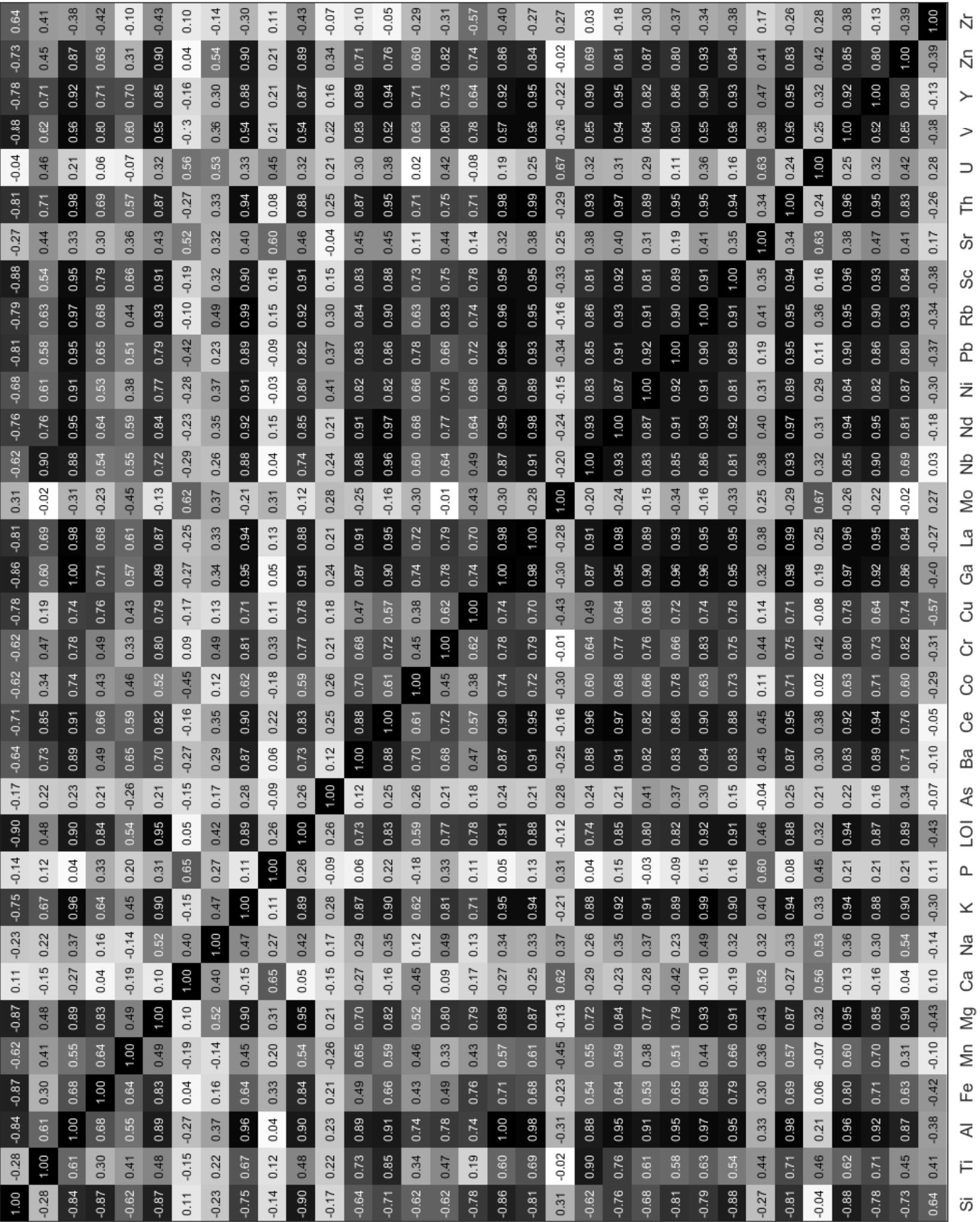

क 
Figure DF2. PCA correlation, Hole M0028A.

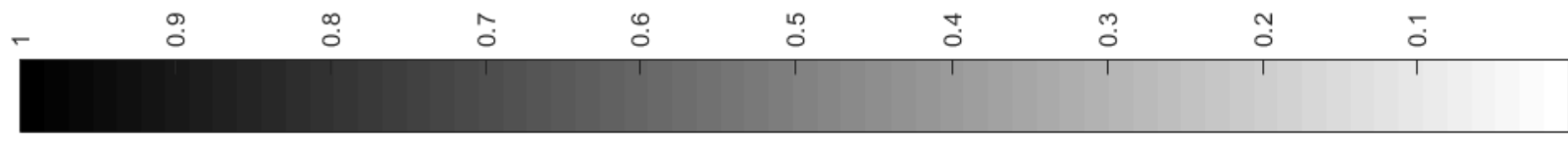

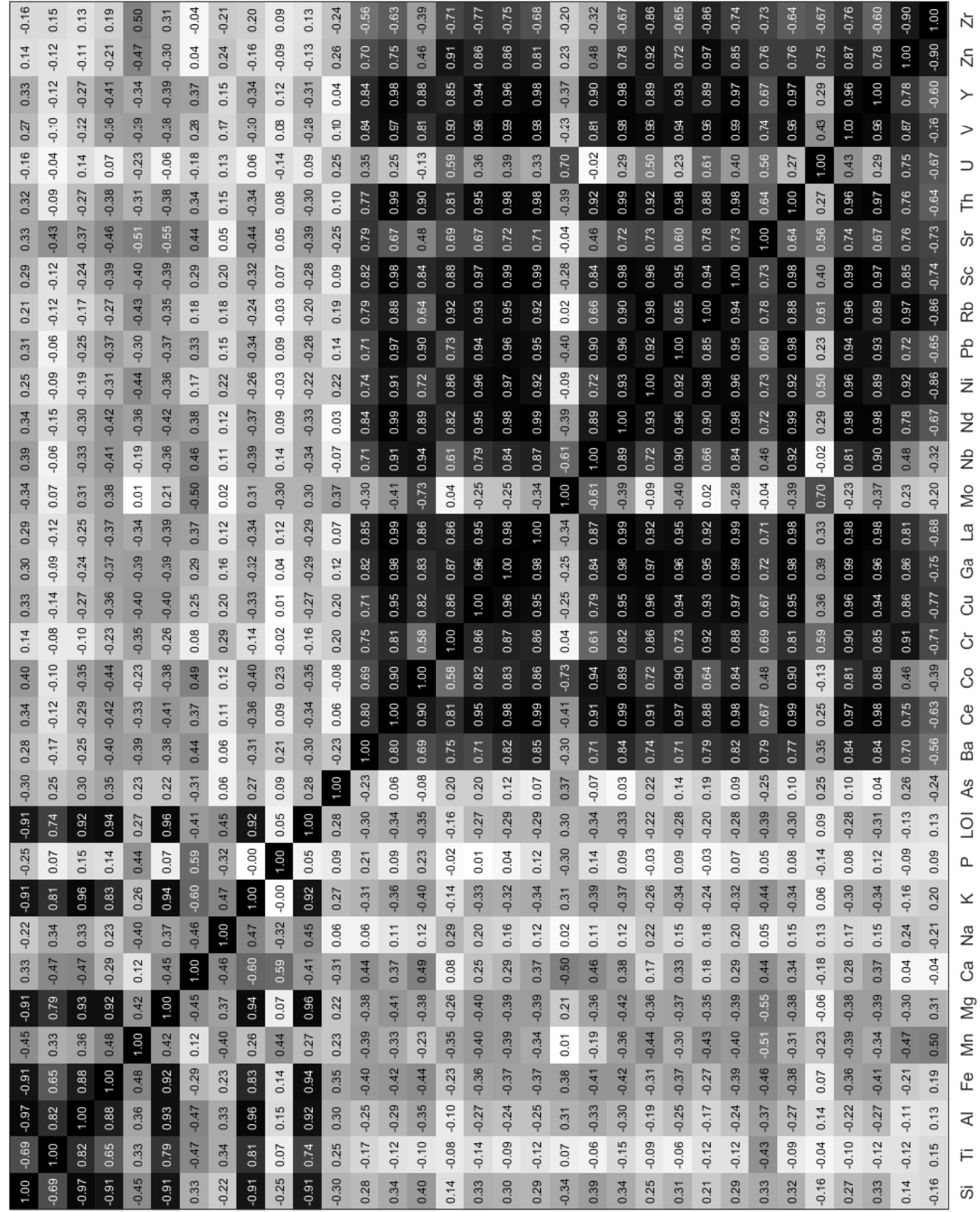

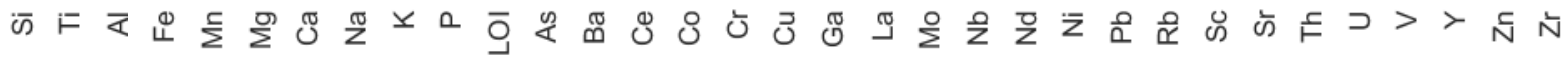


Figure DF3. PCA correlation, Hole M0029A.

\begin{tabular}{llllllllll}
0 & 0 & 0 & 0 & 0 & 0 & 0 & 0 & 0 & 0 \\
0 & 0 & 0 & 0 & 0 & 0 & 0 & 0 & 0 \\
\hline
\end{tabular}

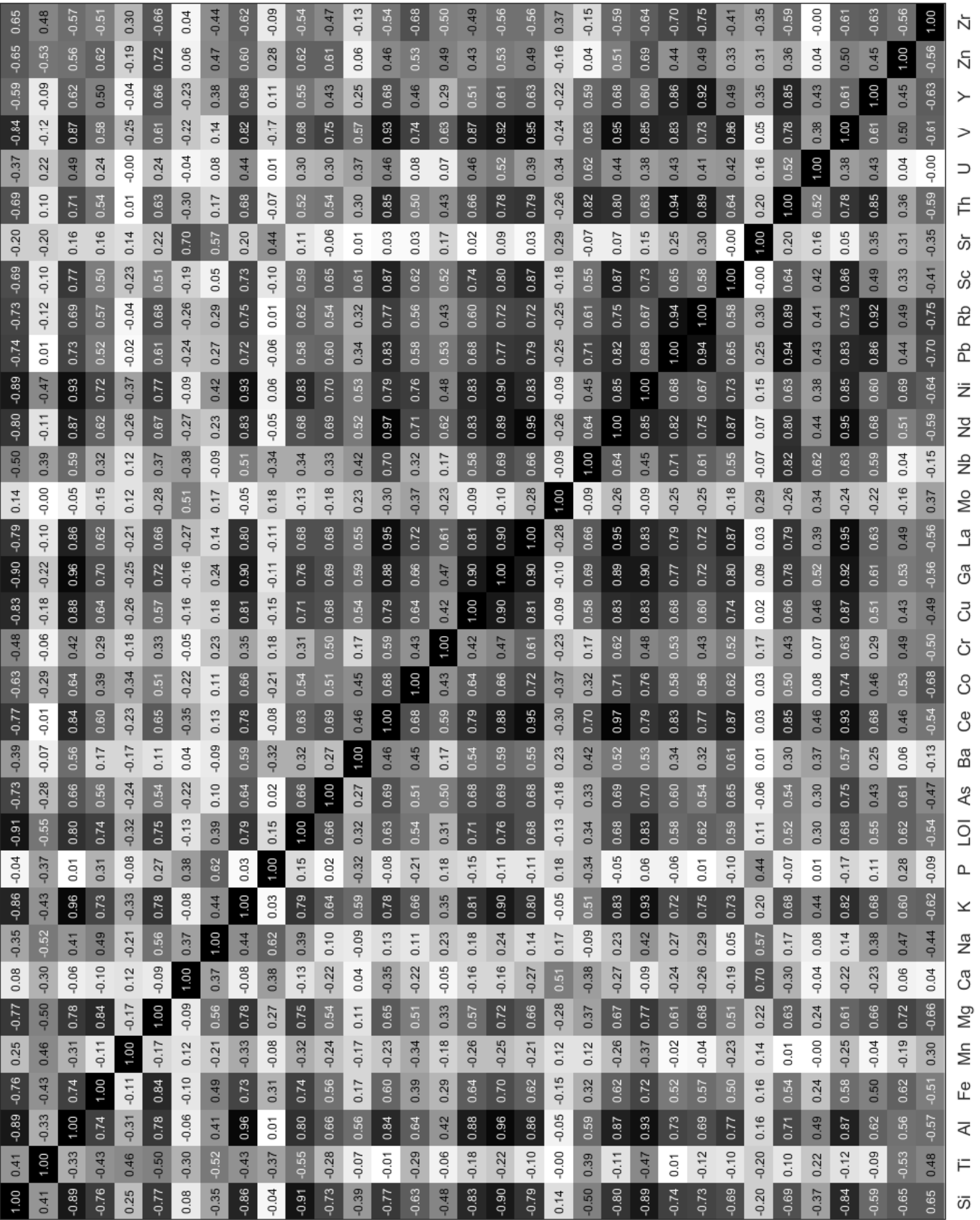

क 
Figure DF4. Principal component summary, Hole M0027A.

M27 PCA Results

$N b$. Cs, Sn and W have been removed due to several values extremely low

\begin{tabular}{|c|c|c|c|c|c|c|c|c|c|c|c|c|}
\hline & & PC1 & PC2 & PC3 & PC4 & PC5 & PC6 & PC7 & PC8 & PC9 & PC10 & PC11 \\
\hline 1 & $\mathrm{La}$ & 0.2176 & -0.0255 & 0.0605 & -0.0182 & -0.0447 & -0.004 & -0.0213 & 0.0839 & -0.0799 & -0.0455 & -0.0723 \\
\hline 2 & $\mathrm{Al} 2 \mathrm{O} 3$ & 0.2176 & -0.0544 & 0.0099 & 0.0457 & -0.0957 & 0.0152 & -0.0119 & -0.0263 & 0.0113 & -0.0389 & -0.0621 \\
\hline 3 & $\mathrm{Ga}$ & 0.2175 & -0.0615 & -0.0041 & 0.0336 & -0.0538 & 0.0268 & 0.0054 & -0.0261 & -0.0507 & -0.078 & -0.0819 \\
\hline 4 & $\mathrm{~V}$ & 0.2168 & -0.0068 & -0.0544 & -0.037 & 0.0419 & -0.0853 & 0.0594 & 0.001 & -0.0758 & -0.0813 & -0.0996 \\
\hline 5 & Th & 0.2167 & -0.0367 & 0.0712 & 0.0119 & -0.0016 & -0.0585 & 0.0424 & 0.0157 & -0.0373 & 0.0255 & -0.1569 \\
\hline 6 & $\mathrm{Rb}$ & 0.2153 & 0.0378 & -0.0256 & 0.0947 & -0.067 & -0.1045 & -0.0258 & -0.0503 & 0.0374 & 0.0427 & -0.0692 \\
\hline 7 & $\mathrm{Nd}$ & 0.2134 & 0.0054 & 0.1138 & -0.0247 & -0.0383 & -0.0407 & 0.0127 & 0.0814 & -0.1111 & -0.0738 & -0.072 \\
\hline 8 & $\mathrm{~K} 2 \mathrm{O}$ & 0.2129 & 0.0243 & 0.0188 & 0.0843 & -0.0971 & -0.1461 & -0.0317 & -0.0563 & 0.1245 & -0.0194 & -0.0439 \\
\hline 9 & $\mathrm{Sc}$ & 0.2128 & -0.0545 & -0.0599 & -0.0739 & -0.024 & 0.0542 & 0.0581 & 0.1037 & -0.0244 & 0.1774 & 0.0102 \\
\hline 10 & $Y$ & 0.2107 & 0.0182 & 0.0851 & -0.1132 & 0.0189 & 0.0991 & 0.0433 & 0.0739 & -0.0542 & 0.1996 & 0.1154 \\
\hline 11 & LOI & 0.2066 & 0.0476 & -0.1585 & -0.0129 & 0.0856 & 0.0476 & 0.0679 & -0.1564 & 0.0323 & 0.0919 & -0.0223 \\
\hline 12 & $\mathrm{~Pb}$ & 0.206 & -0.1227 & 0.0534 & 0.1155 & 0.0566 & 0.0587 & -0.0298 & -0.0209 & -0.0022 & -0.0436 & -0.0763 \\
\hline 13 & $\mathrm{MgO}$ & 0.2044 & 0.067 & -0.1858 & -0.0107 & 0.0059 & -0.1176 & 0.1494 & -0.0149 & 0.035 & 0.1031 & -0.0045 \\
\hline 14 & $\mathrm{Ni}$ & 0.1991 & -0.0185 & 0.0637 & 0.1958 & -0.031 & -0.0131 & -0.2355 & -0.1202 & 0.0049 & -0.0044 & 0.2673 \\
\hline 15 & $\mathrm{Nb}$ & 0.1967 & 0.0134 & 0.2601 & -0.019 & 0.0398 & -0.1112 & 0.1044 & -0.1163 & -0.0481 & -0.0909 & -0.0956 \\
\hline 16 & $\mathrm{Zn}$ & 0.1965 & 0.0841 & -0.1266 & 0.1644 & -0.0761 & 0.0116 & -0.1645 & 0.0024 & 0.0424 & 0.3655 & 0.0469 \\
\hline 17 & $\mathrm{Ba}$ & 0.1953 & -0.0046 & 0.1938 & -0.0644 & -0.1759 & 0.1587 & -0.0691 & -0.0155 & 0.0584 & -0.2331 & 0.2225 \\
\hline 18 & $\mathrm{Ce}$ & 0.1863 & 0.065 & 0.145 & -0.043 & 0.0663 & -0.0765 & 0.097 & 0.0431 & -0.0497 & -0.0744 & -0.1168 \\
\hline 19 & $\mathrm{SiO} 2$ & -0.1883 & 0.0944 & 0.2376 & 0.0697 & -0.1077 & -0.1665 & -0.1737 & 0.1314 & 0.0654 & 0.2038 & 0.13 \\
\hline 20 & $\mathrm{Cr}$ & 0.1781 & 0.1205 & -0.094 & 0.073 & -0.1886 & -0.1207 & -0.3826 & 0.2448 & -0.3191 & -0.1473 & 0.2382 \\
\hline 21 & $\mathrm{Cu}$ & 0.165 & -0.1297 & -0.2695 & -0.0104 & 0.1357 & -0.3419 & -0.2491 & -0.1103 & 0.0151 & 0.3089 & 0.1935 \\
\hline 22 & $\mathrm{Fe} 2 \mathrm{O} 3$ & 0.1649 & -0.0295 & -0.2435 & -0.1802 & 0.4147 & -0.0019 & 0.2839 & -0.0409 & 0.0462 & 0.1204 & 0.0764 \\
\hline 23 & Co & 0.1542 & -0.1585 & 0.0922 & 0.0974 & -0.0745 & 0.6205 & 0.0043 & 0.3131 & 0.1049 & 0.3171 & -0.236 \\
\hline 24 & $\mathrm{TiO} 2$ & 0.1449 & 0.128 & 0.4102 & -0.06 & 0.1152 & -0.2278 & 0.1089 & -0.0869 & -0.0092 & -0.122 & -0.0913 \\
\hline 25 & $\mathrm{MnO}$ & 0.1313 & -0.1067 & 0.0425 & -0.4814 & 0.0657 & 0.249 & 0.102 & -0.0285 & -0.0669 & -0.1125 & 0.5558 \\
\hline 26 & $\mathrm{Sr}$ & 0.0923 & 0.3238 & 0.016 & -0.2614 & -0.0298 & 0.2253 & -0.3833 & -0.2775 & 0.5293 & -0.155 & -0.0527 \\
\hline 27 & $\mathrm{Na} 2 \mathrm{O}$ & 0.0848 & 0.2724 & -0.1221 & 0.2551 & -0.4057 & -0.0963 & 0.4995 & 0.258 & 0.3621 & -0.0832 & 0.2946 \\
\hline 28 & $\mathrm{Zr}$ & -0.0713 & 0.1947 & 0.4761 & -0.1503 & 0.1462 & -0.1451 & 0.0196 & 0.1682 & 0.1075 & 0.4835 & 0.1853 \\
\hline 29 & $U$ & 0.0642 & 0.4253 & 0.0944 & 0.1026 & -0.0285 & 0.1569 & -0.0652 & -0.2283 & -0.2471 & 0.1526 & -0.1444 \\
\hline 30 & As & 0.0569 & 0.0422 & 0.0422 & 0.4859 & 0.6339 & 0.086 & -0.1071 & 0.169 & 0.2823 & -0.213 & 0.1591 \\
\hline 31 & Mo & -0.0525 & 0.3914 & -0.0123 & 0.24 & 0.1519 & 0.2861 & 0.1392 & -0.1184 & -0.4489 & -0.0363 & 0.2121 \\
\hline 32 & $\mathrm{CaO}$ & -0.0369 & 0.41 & -0.269 & -0.1289 & -0.0208 & 0.0141 & 0.0793 & -0.1754 & 0.057 & 0.1135 & -0.1039 \\
\hline 33 & P2O5 & 0.0362 & 0.3291 & -0.188 & -0.313 & 0.172 & -0.0807 & -0.1823 & 0.6356 & -0.054 & -0.1656 & -0.2024 \\
\hline \multicolumn{2}{|c|}{ Explained } & 62.0399 & 11.9706 & 7.5757 & 5.9719 & 2.8129 & 2.152 & 1.5387 & 1.2071 & 0.9675 & 0.7966 & 0.6049 \\
\hline
\end{tabular}

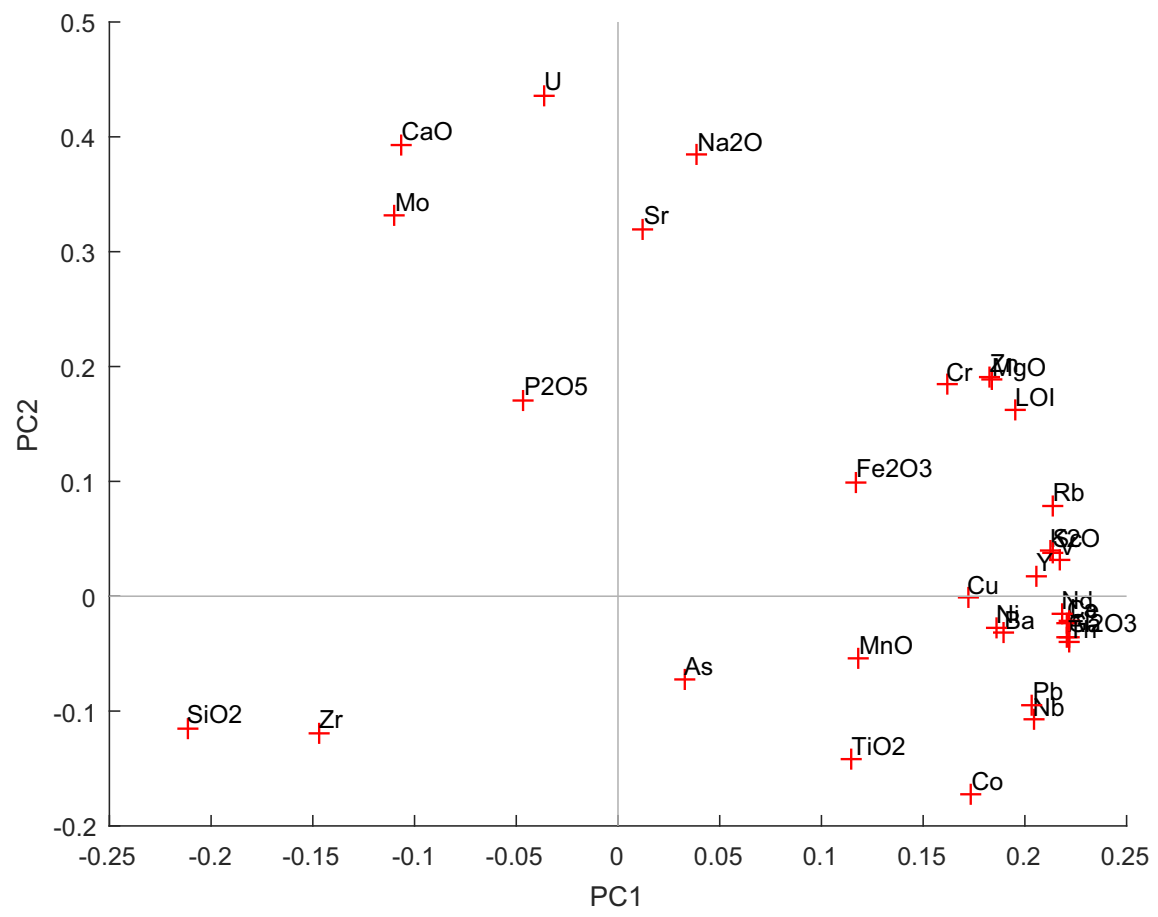


Figure DF5. Principal component summary, Hole M0028A.

M28 PCA Results

$\mathrm{Nb}$. Cs, Sn and $W$ have been removed due to several values extremely low

\begin{tabular}{|c|c|c|c|c|c|c|c|c|c|c|c|c|}
\hline & & PC1 & PC2 & PC3 & PC4 & PC5 & PC6 & PC7 & PC8 & PC9 & PC10 & PC11 \\
\hline 1 & $\mathrm{Nd}$ & 0.2318 & 0.038 & -0.0851 & 0.0163 & 0.0019 & -0.0502 & -0.0476 & -0.0447 & -0.0695 & -0.0526 & -0.076 \\
\hline 2 & Sc & 0.2317 & 0.0726 & -0.029 & 0.0157 & 0.0129 & -0.0072 & 0.0143 & 0.0281 & 0.0216 & -0.0677 & -0.1149 \\
\hline 3 & $\mathrm{Ga}$ & 0.2313 & 0.0746 & -0.0237 & 0.0077 & 0.0431 & -0.057 & -0.0114 & -0.0705 & -0.0089 & 0.0627 & 0.0139 \\
\hline 4 & V & 0.2307 & 0.0822 & -0.0148 & -0.0144 & 0.0022 & -0.0511 & 0.0635 & -0.0112 & -0.0182 & -0.0466 & 0.0489 \\
\hline 5 & La & 0.2305 & 0.0584 & -0.0762 & -0.0178 & 0.0046 & -0.0605 & -0.0226 & 0.0158 & -0.1338 & -0.0256 & -0.0207 \\
\hline 6 & $\mathrm{Ce}$ & 0.2293 & 0.038 & -0.1031 & 0.0298 & 0.0544 & -0.0847 & -0.0452 & -0.0177 & -0.087 & -0.0833 & -0.1442 \\
\hline 7 & $Y$ & 0.2278 & 0.0471 & -0.0945 & 0.0214 & 0.0054 & -0.0791 & 0.0219 & 0.1557 & -0.1248 & 0.0861 & -0.0225 \\
\hline 8 & Th & 0.2274 & 0.0526 & -0.1052 & 0.0338 & 0.0905 & -0.0613 & -0.0898 & 0.0044 & 0.0381 & 0.0251 & -0.1654 \\
\hline 9 & $\mathrm{Cu}$ & 0.2261 & 0.0716 & -0.0032 & 0.029 & 0.1298 & 0.1133 & -0.0869 & -0.0448 & -0.007 & -0.1221 & 0.0882 \\
\hline 10 & $\mathrm{Ni}$ & 0.2223 & 0.108 & 0.065 & -0.0013 & 0.0793 & 0.0581 & -0.0349 & -0.1701 & 0.0716 & -0.0206 & 0.0213 \\
\hline 11 & $\mathrm{~Pb}$ & 0.2212 & 0.0537 & -0.1148 & 0.0453 & 0.1336 & 0.0222 & -0.1009 & -0.1563 & 0.167 & 0.087 & -0.2647 \\
\hline 12 & $\mathrm{Rb}$ & 0.2189 & 0.1172 & 0.1086 & -0.0708 & 0.0015 & -0.0309 & -0.0417 & -0.0522 & -0.082 & -0.0093 & 0.1643 \\
\hline 13 & $\mathrm{Ba}$ & 0.1996 & 0.0181 & -0.0465 & -0.0692 & -0.3362 & -0.1705 & 0.2596 & 0.0652 & -0.2396 & 0.1674 & 0.371 \\
\hline 14 & $\mathrm{Cr}$ & 0.1995 & 0.1374 & 0.0992 & -0.0381 & -0.0009 & -0.1086 & 0.1172 & 0.4428 & -0.1656 & -0.2189 & 0.2712 \\
\hline 15 & Co & 0.1993 & -0.031 & -0.2687 & 0.1208 & 0.0423 & 0.0993 & -0.013 & -0.0252 & 0.0754 & -0.1028 & 0.0491 \\
\hline 16 & $\mathrm{Nb}$ & 0.1989 & -0.0159 & -0.2432 & 0.1121 & 0.0625 & -0.1533 & -0.1385 & 0.1624 & 0.0662 & 0.3496 & -0.1779 \\
\hline 17 & $\mathrm{Zn}$ & 0.1964 & 0.1458 & 0.214 & -0.0907 & -0.0092 & 0.0266 & 0.0304 & 0.0304 & -0.0452 & 0.032 & 0.1245 \\
\hline 18 & $\mathrm{Sr}$ & 0.1866 & -0.0227 & 0.158 & -0.1421 & -0.3888 & 0.0636 & -0.0508 & -0.0373 & 0.1704 & -0.1827 & -0.1643 \\
\hline 19 & $\mathrm{Zr}$ & -0.173 & -0.1199 & -0.2376 & 0.0879 & 0.0096 & -0.2784 & 0.0339 & 0.437 & -0.2931 & 0.2191 & -0.2874 \\
\hline 20 & $\mathrm{MgO}$ & -0.1315 & 0.3031 & -0.1531 & 0.06 & -0.0828 & -0.025 & -0.1381 & 0.0211 & -0.0931 & -0.036 & 0.1176 \\
\hline 21 & $\mathrm{Fe} 2 \mathrm{O} 3$ & -0.1253 & 0.2969 & -0.0967 & -0.1319 & -0.04 & 0.1276 & -0.4103 & -0.0161 & -0.1196 & 0.1144 & 0.2003 \\
\hline 22 & K2O & -0.1151 & 0.3301 & -0.0674 & 0.1054 & -0.0984 & -0.0398 & 0.1582 & 0.0176 & -0.1347 & -0.1521 & -0.0891 \\
\hline 23 & $\mathrm{SiO} 2$ & 0.1089 & -0.3195 & 0.1053 & 0.1627 & 0.137 & -0.0062 & 0.0359 & 0.0226 & 0.1216 & 0.248 & 0.3272 \\
\hline 24 & $\mathrm{MnO}$ & -0.1077 & 0.0443 & -0.2694 & -0.3647 & 0.2433 & -0.3395 & -0.1872 & 0.2775 & 0.461 & -0.347 & 0.2309 \\
\hline 25 & LOI & -0.106 & 0.3315 & -0.0883 & 0.0331 & -0.1348 & 0.1568 & -0.2522 & -0.0448 & -0.107 & 0.1551 & 0.0622 \\
\hline 26 & $\mathrm{Al} 2 \mathrm{O} 3$ & -0.0997 & 0.344 & -0.1034 & -0.0345 & -0.1014 & -0.0752 & 0.1181 & -0.1183 & -0.0622 & -0.1442 & -0.233 \\
\hline 27 & $\mathrm{CaO}$ & 0.0917 & -0.1892 & -0.2403 & -0.3505 & -0.2462 & 0.2296 & -0.3665 & 0.0344 & -0.0039 & 0.2798 & 0.0774 \\
\hline 28 & U & 0.085 & 0.1787 & 0.363 & -0.2562 & -0.1066 & -0.1973 & -0.0048 & 0.1476 & 0.2613 & 0.182 & -0.3239 \\
\hline 29 & Mo & -0.0731 & 0.1533 & 0.4244 & -0.2247 & 0.0706 & -0.1422 & -0.0754 & 0.1032 & 0.0137 & 0.3283 & -0.0135 \\
\hline 30 & TiO2 & -0.0659 & 0.2947 & -0.1938 & 0.1337 & 0.0564 & -0.3076 & 0.283 & -0.3262 & 0.3353 & 0.3757 & 0.2327 \\
\hline 31 & $\mathrm{Na} 2 \mathrm{O}$ & 0.0236 & 0.2108 & 0.0559 & 0.4712 & -0.1595 & 0.4028 & 0.0143 & 0.4856 & 0.4241 & 0.0654 & 0.0354 \\
\hline 32 & P2O5 & 0.0111 & 0.004 & -0.3191 & -0.4612 & -0.1299 & 0.3638 & 0.5384 & 0.0737 & 0.1347 & 0.1078 & -0.0769 \\
\hline 33 & As & 0.0027 & 0.193 & 0.0584 & -0.183 & 0.6548 & 0.3627 & 0.1411 & 0.113 & -0.1934 & 0.1277 & -0.0295 \\
\hline \multicolumn{2}{|c|}{ Explained } & 53.9377 & 18.9812 & 10.0709 & 5.8322 & 3.9565 & 1.8567 & 1.3082 & 1.1878 & 0.763 & 0.5977 & 0.4795 \\
\hline
\end{tabular}

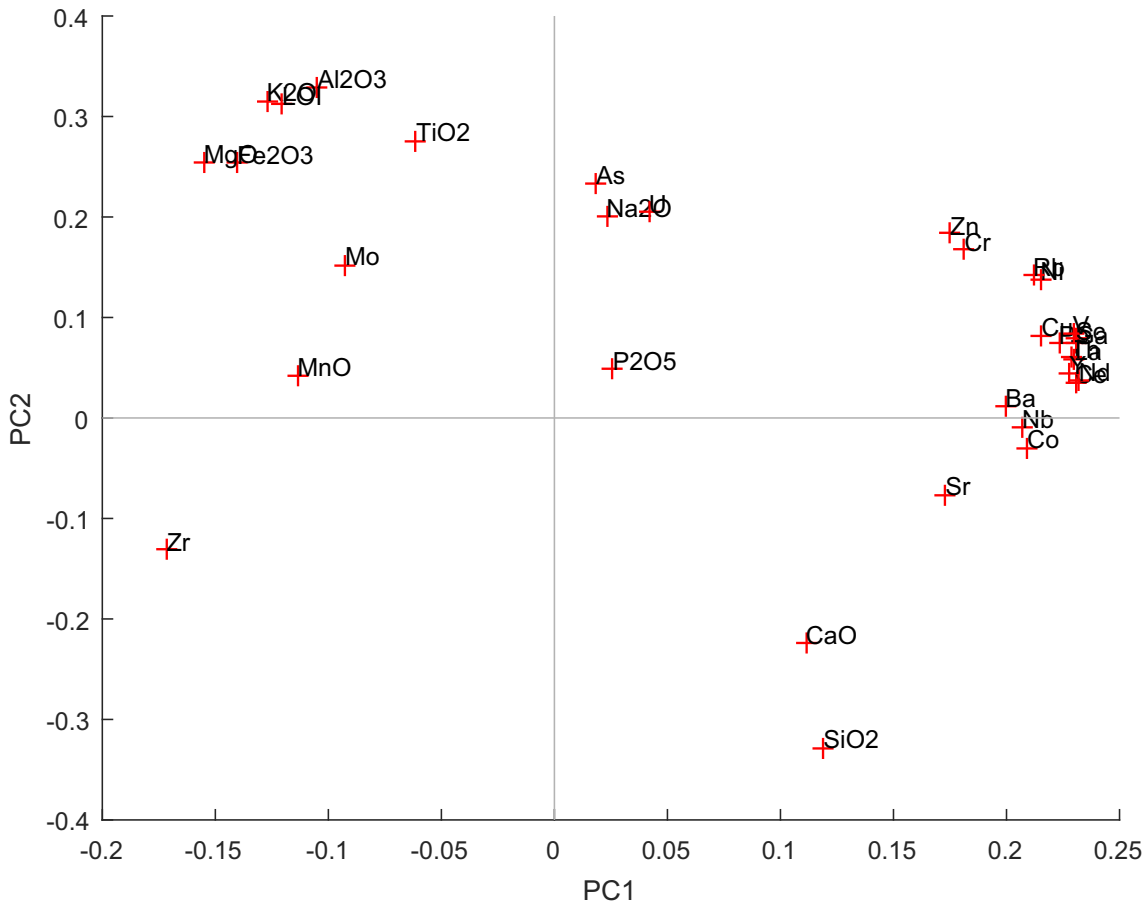


Figure DF6. Principal component summary, Hole M0029A.

M29 PCA Results

$N b$. Cs, Sn and $W$ have been removed due to several values extremely low

\begin{tabular}{|c|c|c|c|c|c|c|c|c|c|c|c|c|}
\hline & & PC1 & PC2 & PC3 & PC4 & PC5 & PC6 & PC7 & PC8 & PC9 & PC10 & PC11 \\
\hline 1 & $\mathrm{Ga}$ & 0.228 & -0.049 & 0.036 & 0.129 & -0.047 & 0.003 & 0.058 & -0.048 & -0.172 & 0.008 & 0.005 \\
\hline 2 & $\mathrm{Nd}$ & 0.227 & -0.081 & -0.017 & 0.010 & 0.092 & 0.118 & -0.090 & -0.137 & 0.058 & 0.052 & 0.046 \\
\hline 3 & $\mathrm{Al} 2 \mathrm{O} 3$ & 0.226 & 0.030 & 0.046 & 0.154 & -0.078 & -0.030 & -0.001 & -0.140 & -0.149 & 0.033 & 0.000 \\
\hline 4 & V & 0.226 & -0.100 & -0.043 & 0.059 & 0.159 & 0.074 & 0.042 & -0.005 & -0.076 & -0.057 & -0.081 \\
\hline 5 & $\mathrm{Ni}$ & 0.224 & 0.081 & -0.053 & 0.148 & -0.021 & -0.033 & 0.020 & 0.007 & -0.002 & 0.200 & 0.056 \\
\hline 6 & La & 0.223 & -0.103 & -0.038 & 0.026 & 0.092 & 0.110 & 0.022 & -0.185 & 0.059 & 0.011 & 0.043 \\
\hline 7 & $\mathrm{~K} 2 \mathrm{O}$ & 0.222 & 0.066 & 0.031 & 0.135 & -0.081 & -0.156 & -0.024 & -0.060 & 0.089 & 0.107 & 0.002 \\
\hline 8 & $\mathrm{Ce}$ & 0.222 & -0.128 & -0.009 & -0.038 & 0.050 & 0.144 & -0.093 & -0.116 & 0.028 & -0.013 & 0.132 \\
\hline 9 & $\mathrm{SiO} 2$ & -0.221 & -0.072 & 0.022 & -0.064 & 0.080 & -0.004 & -0.164 & -0.124 & 0.189 & 0.175 & 0.130 \\
\hline 10 & $\mathrm{~Pb}$ & 0.208 & -0.078 & 0.128 & -0.229 & 0.096 & -0.069 & -0.034 & 0.131 & -0.027 & -0.053 & -0.224 \\
\hline 11 & $\mathrm{Cu}$ & 0.208 & -0.064 & -0.007 & 0.177 & -0.036 & 0.026 & 0.078 & 0.013 & -0.320 & -0.093 & -0.114 \\
\hline 12 & $\mathrm{Rb}$ & 0.202 & -0.022 & 0.119 & -0.258 & 0.016 & -0.198 & -0.046 & 0.175 & 0.212 & -0.028 & -0.169 \\
\hline 13 & Th & 0.201 & -0.129 & 0.167 & -0.238 & -0.026 & -0.040 & -0.057 & 0.032 & -0.054 & -0.109 & 0.002 \\
\hline 14 & Sc & 0.196 & -0.118 & -0.021 & 0.144 & 0.129 & 0.160 & -0.032 & -0.203 & 0.287 & -0.285 & 0.117 \\
\hline 15 & LOI & 0.195 & 0.126 & -0.083 & 0.096 & -0.243 & -0.028 & 0.084 & 0.116 & 0.047 & -0.217 & -0.127 \\
\hline 16 & $\mathrm{MgO}$ & 0.192 & 0.176 & -0.036 & -0.131 & -0.253 & -0.027 & 0.101 & -0.195 & -0.025 & 0.077 & 0.192 \\
\hline 17 & $\mathrm{Y}$ & 0.181 & 0.002 & 0.177 & -0.286 & -0.055 & -0.222 & -0.179 & 0.105 & 0.296 & 0.051 & 0.037 \\
\hline 18 & As & 0.179 & -0.004 & -0.137 & 0.053 & -0.045 & 0.299 & 0.140 & 0.514 & 0.113 & -0.201 & 0.016 \\
\hline 19 & $\mathrm{Fe} 2 \mathrm{O} 3$ & 0.177 & 0.158 & -0.019 & -0.033 & -0.331 & 0.128 & 0.194 & -0.262 & 0.005 & -0.037 & -0.125 \\
\hline 20 & Co & 0.176 & -0.026 & -0.225 & 0.028 & 0.255 & -0.238 & 0.050 & -0.011 & 0.009 & 0.254 & 0.308 \\
\hline 21 & $\mathrm{Zr}$ & -0.169 & -0.156 & 0.123 & 0.229 & -0.230 & 0.275 & 0.054 & -0.127 & 0.113 & 0.124 & 0.197 \\
\hline 22 & $\mathrm{Zn}$ & 0.152 & 0.245 & -0.123 & -0.074 & 0.018 & 0.132 & 0.265 & 0.281 & 0.075 & 0.466 & 0.341 \\
\hline 23 & $\mathrm{Nb}$ & 0.150 & -0.292 & 0.230 & -0.058 & -0.158 & -0.046 & -0.008 & -0.106 & -0.196 & 0.059 & 0.026 \\
\hline 24 & $\mathrm{Cr}$ & 0.134 & 0.032 & -0.089 & -0.112 & 0.448 & 0.490 & -0.082 & 0.025 & -0.089 & 0.186 & -0.277 \\
\hline 25 & $\mathrm{Ba}$ & 0.119 & -0.140 & 0.104 & 0.411 & 0.217 & -0.227 & 0.026 & -0.158 & 0.453 & 0.100 & -0.157 \\
\hline 26 & $U$ & 0.107 & -0.125 & 0.389 & 0.152 & -0.203 & 0.114 & -0.253 & 0.284 & -0.058 & -0.018 & 0.377 \\
\hline 27 & $\mathrm{Na} 2 \mathrm{O}$ & 0.082 & 0.381 & 0.144 & -0.070 & -0.056 & -0.011 & -0.238 & -0.242 & -0.215 & 0.301 & -0.214 \\
\hline 28 & $\mathrm{TiO} 2$ & -0.068 & -0.379 & 0.227 & -0.166 & 0.082 & 0.222 & -0.030 & -0.076 & -0.183 & 0.178 & 0.079 \\
\hline 29 & $\mathrm{MnO}$ & -0.064 & -0.104 & 0.304 & -0.241 & -0.031 & 0.095 & 0.705 & -0.129 & 0.210 & 0.089 & -0.124 \\
\hline 30 & Mo & -0.053 & 0.102 & 0.402 & 0.383 & -0.022 & 0.052 & -0.017 & 0.286 & 0.050 & 0.306 & -0.340 \\
\hline 31 & $\mathrm{CaO}$ & -0.048 & 0.304 & 0.285 & 0.202 & 0.334 & -0.018 & 0.214 & -0.095 & -0.173 & -0.309 & 0.194 \\
\hline 32 & $\mathrm{Sr}$ & 0.041 & 0.288 & 0.380 & -0.117 & 0.324 & -0.119 & 0.061 & 0.020 & -0.084 & -0.159 & 0.248 \\
\hline 33 & P2O5 & 0.002 & 0.363 & 0.127 & -0.108 & -0.097 & 0.402 & -0.278 & -0.150 & 0.344 & -0.133 & 0.026 \\
\hline \multicolumn{2}{|c|}{ Explained } & 52.437 & 12.107 & 7.393 & 6.463 & 4.102 & 3.340 & 2.701 & 1.858 & 1.409 & 1.303 & 1.175 \\
\hline
\end{tabular}

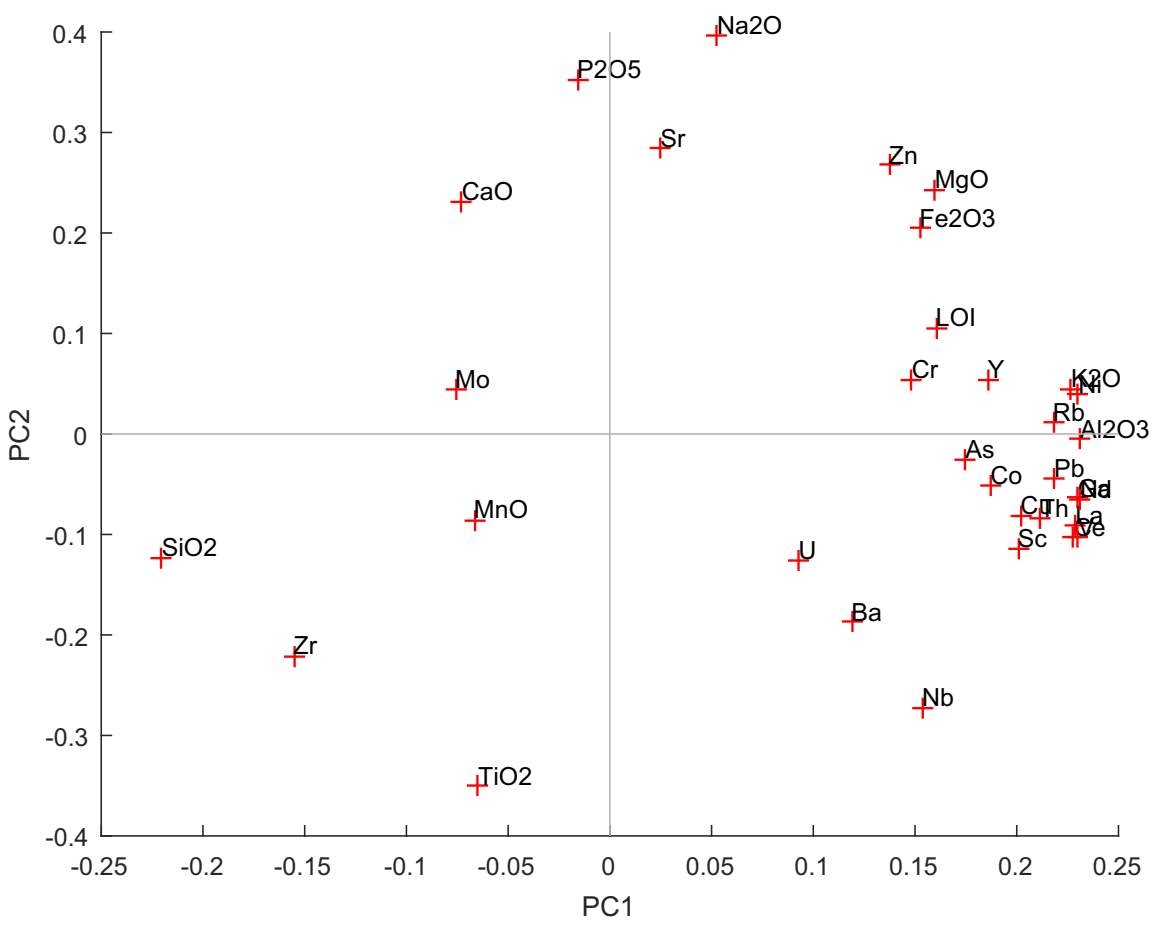


Table AT1. Depth scale conversion for the analyzed interval in Hole M0027A. This table is available in CSV format.

Table AT2. Depth scale conversion for the analyzed interval in Hole M0028A. This table is available in CSV format.

Table AT3. Depth scale conversion for the analyzed interval in Hole M0029A. This table is available in CSV format.

Table BT1. X-ray fluorescence data, Hole M0027A. This table is available in CSV format.

Table BT2. X-ray fluorescence data, Hole M0028A. This table is available in CSV format.

Table BT3. X-ray fluorescence data, Hole M0029A. This table is available in CSV format.

Table CT1. Sample X-ray fluorescence data, Hole M0027A. This table is available in CSV format.

Table CT2. Sample X-ray fluorescence data, Hole M0028A. This table is available in CSV format.

Table CT3. Sample X-ray fluorescence data, Hole M0029A. This table is available in CSV format. 